Review

\title{
Covid 19: Diet Composition and Health
}

\author{
Dorota Skrajnowska (D), Maja Brumer, Sylwia Kankowska, Magdalena Matysek, Natalia Miazio \\ and Barbara Bobrowska-Korczak *(D)
}

\begin{abstract}
Department of Bromatology, Medical University of Warsaw, Banacha 1, 02-097 Warsaw, Poland; dorota.skrajnowska@wum.edu.pl (D.S.); s072231@student.wum.edu.pl (M.B.);

s073006@student.wum.edu.pl (S.K.); s077164@student.wum.edu.pl (M.M.); s077158@student.wum.edu.pl (N.M.)

* Correspondence: barbara.bobrowska@wum.edu.pl; Tel./Fax: +48-225-720-785
\end{abstract}

check for

updates

Citation: Skrajnowska, D.; Brumer,

M.; Kankowska, S.; Matysek, M.;

Miazio, N.; Bobrowska-Korczak, B.

Covid 19: Diet Composition and

Health. Nutrients 2021, 13, 2980.

https://doi.org/10.3390/nu13092980

Academic Editor: Rosa Casas

Received: 9 July 2021

Accepted: 26 August 2021

Published: 27 August 2021

Publisher's Note: MDPI stays neutral with regard to jurisdictional claims in published maps and institutional affiliations.

Copyright: (c) 2021 by the authors. Licensee MDPI, Basel, Switzerland. This article is an open access article distributed under the terms and conditions of the Creative Commons Attribution (CC BY) license (https:/ / creativecommons.org/licenses/by/ $4.0 /)$.
Abstract: The virus severe acute respiratory syndrome coronavirus 2 (SARS-CoV-2) causes the disease coronavirus disease 2019 (COVID-19). The cumulative number of cases reported globally is now nearly 197 million and the number of cumulative deaths is 4.2 million (26 July to 1 August 2021). Currently we are focusing primarily on keeping a safe distance from others, washing our hands, and wearing masks, and the question of the effects of diet and diet-dependent risk factors remains outside the center of attention. Nevertheless, numerous studies indicate that diet can play an important role in the course of COVID-19. In this paper, based on select scientific reports, we discuss the structure and replication cycle of SARS-CoV-2, risk factors, dietary standards for sick patients, and the roles of the microbiome and dietary components supporting the immune system in preventing COVID-19.

Keywords: virus SARS-CoV-2; nutritional status; dietary components; defense mechanism

\section{Description of the SARS-CoV-2 Virus}

The virus SARS-CoV-2 (Severe Acute Respiratory Syndrome Coronavirus 2) causes the disease COVID-19 (Coronavirus Disease 2019). The cumulative number of cases reported globally is now nearly 197 million and the number of cumulative deaths is 4.2 million (26 July to 1 August 2021) [1]. The original carriers of SARS-CoV were bats. In 2019 the interspecific barrier was breached, with tragic consequences. The transmission of the virus from bats to humans most likely involved an intermediate host, i.e., the Asian palm civet, sold at wildlife markets in the Chinese province of Wuhan [2]. The SARS-CoV-2 virus is transmitted by airborne droplets and as an aerosol. Infection can take place as a result of direct content with a carrier or indirectly through contact with the environment in which a carrier has been present, as the virus can survive from 4 to $72 \mathrm{~h}$, depending on the type of surface [3]. SARS-CoV-2 is a $\beta$-coronavirus with a genome comprising a single strand of RNA. In its structure we can distinguish a nucleocapsid consisting of an $\mathrm{N}$ protein and RNA and a lipid bilayer envelope derived from the host cell, composed of both lipids and viral proteins (Figure 1). 


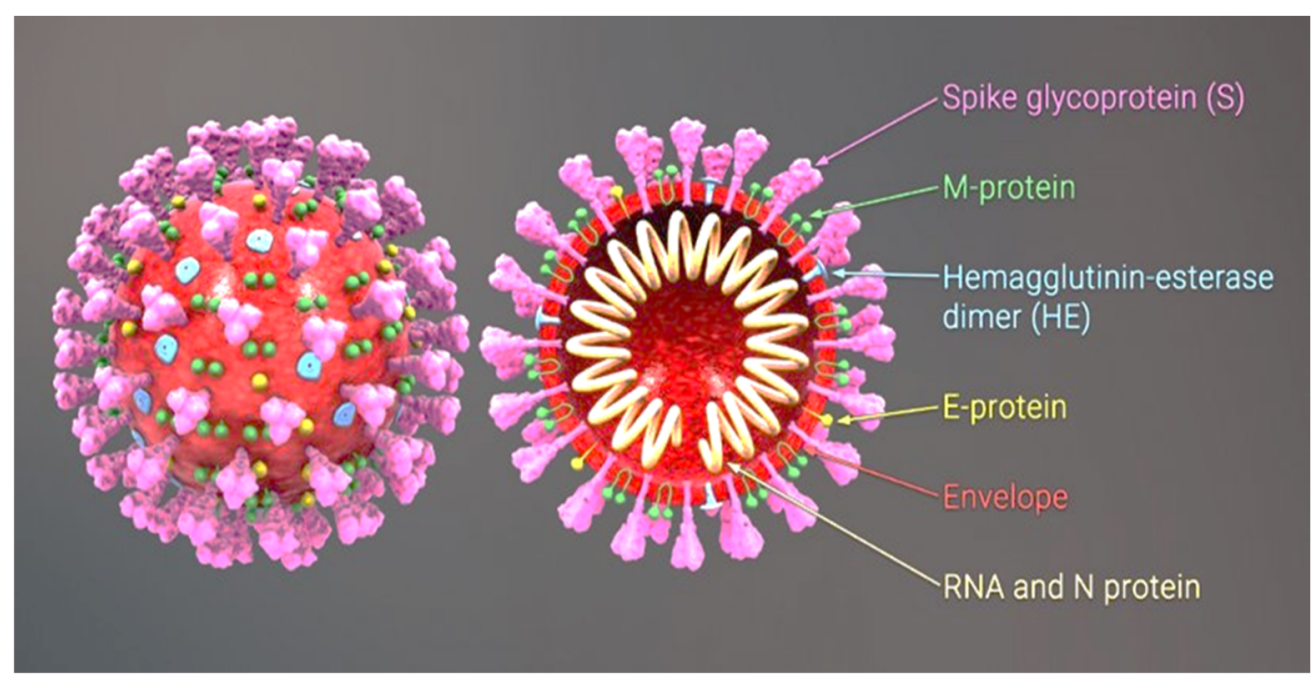

Figure 1. The structure of a coronavirus [4]. E-envelope; $\mathrm{M}$-membrane; S-spike glycoproteins, which allow viral particles to bind to receptors on the host cell membranes.

In the case of SARS-CoV-2, the membrane receptor on the host cell is angiotensinconverting enzyme 2 (ACE2), which the virus uses as a gateway into cells. After the spike protein binds to ACE2, the virus enters the cell by endocytosis [5]. This is followed by cleavage of the $S$ protein at two sites and penetration of the viral genome into the cytoplasm. When the virus penetrates a human cell, it initiates the production of specific viral polyproteins. Next, two viral proteases, i.e., papain-like protease and serine, cleave two polyproteins, ppla and pplab, leading to the formation of nonstructural proteins (NSPs 1-16). NSPs in turn build a replicase-transcriptase complex, which allows the virus to replicate its genetic material. This is followed by synthesis of mRNA, which is a matrix for the translation of the structural proteins S, E, M, and N. These proteins are relocated to the endoplasmic reticulum and then to the endoplasmic reticulum-Golgi intermediate compartment (E-GIC), where penetration of the viral RNA is followed by the formation of mature virions. Virions in the secretory vesicles penetrate the cell membrane, where their contents are released into the extracellular space, resulting in infection and an immune response [5]. Unfortunately, in some cases of COVID-19 the immune response becomes uncontrolled, and an excessive release of cytokines leads to a state of hyperinflammation, manifested as severe acute respiratory distress syndrome (SARDS) and then multi-organ failure [6]. Although the disease is accompanied by increased production of TNF- $\alpha$, IL$1 \beta$, IL-8, IL-12, interferon-gamma inducible protein 10 (IP10), macrophage inflammatory protein 1A (MIP1A), and monocyte chemoattractant protein 11 (MCP1), a critical role is ascribed to another inflammatory cytokine-interleukin 6 (IL-6). IL-6 is produced by active leukocytes and exhibits activity within most cells and tissues [7]. A dramatic increase in the concentration of IL-6 in the body is manifested as high fever and multi-organ failure, which, when accompanied by conditions that already weaken of the body-e.g., chronic inflammation, multi-organ diseases, or mitochondriopathy—can even lead to the patient's death [8].

\section{Angiotensin-Converting Enzyme 2 (ACE2)}

Angiotensin-converting enzyme 2 is a protein present in many types of cells and tissues: in the lungs, heart, blood vessels, kidneys, pancreas, liver, and gastrointestinal tract. It is located in epithelial cells, which line tissues and form protective barriers. In the lungs, it is present in large quantities in type II pneumocytes [9]. ACE2 is a negative regulator of the renin-angiotensin system, facilitating transport of amino acids and the SARS-CoV and SARS-CoV-2 receptors [9]. ACE converts angiotensin I into angiotensin II, but also catalyzes the conversion of angiotensin II to angiotensin 1-7, with vasodilating, anti-inflammatory, antioxidant, and cytoprotective effects [10]. In this way ACE2 lowers blood pressure by 
catalyzing hydrolysis of angiotensin II to angiotensin 1-7. Hence, the ACE2 system is a very important protective pathway against heart failure occurring with a reduced ejection fraction, including against myocardial infarction and hypertension, and against pulmonary diseases and diabetes. Binding of ACE2 by SARS-Co-2 reduces the level of this enzyme in the lungs, which is a likely cause of the severe pulmonary symptoms observed in infected patients [9]. ACE2 also takes part in regulation of blood glucose levels [9]. Diet thus has a certain influence on the activity of angiotensin-converting enzyme; for example, a high-fat diet raises its level [11].

\section{Risk Factors for Severe COVID-19}

Most people infected with the SARS-CoV-2 experience no symptoms or only mild ones. However, there is a long list of factors that may cause a mild infection to transform into a life-threatening condition. The National Health Service (NHS) classifies risk factors for severe COVID-19 as high or moderate [12]. The high-risk group includes cancer patients, transplant recipients, and those with severe pulmonary disease. The other group of factors includes age ( $>70$ years), obesity (BMI $\geq 40$ ), and diabetes. Reports from many countries suggest that obese patients have poor prognoses with the disease. Obesity causes atelectasis and alveolar collapse due to increased pressure in the pleural cavity and reduces lung recruitment capacity $[13,14]$. According to the Centers for Disease Control and Prevention, the most common co-occurring diseases in COVID-19 cases are cardiovascular disease (32\%) and diabetes (30\%) [15]. Two thirds of patients in the United Kingdom with serious cases of COVID-19 were overweight or obese, and 99\% of deaths in Italy were in patients with pre-existing diseases such as hypertension, diabetes, and heart disease [16]. These diseases are jointly referred to as metabolic syndrome (MetS). Metabolic syndrome encompasses a number of interrelated metabolic disorders, such as obesity, impaired glucose tolerance, insulin resistance and/or hyperinsulinemia, dyslipidemia, and hypertension. Their cooccurrence increases the risk of cardiovascular diseases caused by atherosclerosis and type 2 diabetes [17]. Doctors diagnose metabolic syndrome based on guidelines recommended by the International Diabetes Federation in 2009 [18].

One of the factors stimulating metabolic syndrome is insulin resistance, which is impaired sensitivity of tissues to insulin, the hormone regulating the glucose concentration in the blood. This occurs due to a defect of the insulin receptor, or much more often due to disturbances in processes signaling the binding of insulin to the insulin receptor [19]. Clinical observations that severe COVID-19 usually occurs in older patients, in men, and in patients with hypertension, elevated blood glucose levels, and abnormal results from liver function tests suggest that insulin resistance may play an important role in the course of COVID-19 [19]. Angiotensin-converting enzyme 2 (ACE2) is a potentially important molecular link between insulin resistance and severe COVID-19 [20,21]. It functions as a ligand through which coronaviruses bind to target cells [21]. ACE2 is expressed mainly in alveolar epithelial cells, pancreatic beta cells, and enterocytes of the small intestine [20]. As mentioned above, the primary physiological role of ACE2 is conversion of angiotensin 2, with vasoconstrictive and pro-inflammatory effects, to angiotensin (1-7), with a vasodilating effect [22]. Importantly, angiotensin 2 is the dominant component of the renin-angiotensin-aldosterone system (RAAS), which enhances insulin resistance and cardiovascular dysfunction. By degrading angiotensin 2, ACE2 protects against the effects of excessive activation of RAAS. The risk of insulin resistance is reduced owing to a decrease in cellular oxidative stress and enhancement of insulin signaling and glucose transport [23]. Expression of this enzyme is increased in people with diabetes. It is unclear, however, whether it is insulin or glucose itself that affects the ACE2 level. This distinction may be of clinical importance, because it could determine whether normalization of the blood glucose level or the insulin level should be prioritized to reduce ACE2 expression and thus the severity of COVID-19 [19]. It is likely that other mechanisms as well, independent of ACE2 expression, contribute to the severe course of COVID-19 associated with concomitant diabetes. In the pathophysiology of diabetes, particularly in patients with uncontrolled 
glycemia, the innate immune system and humoral resistance are impaired [24]. This means that the first line of defense against any infection, including by SARS-CoV-2, is ineffective. Diabetes also causes inflammation with an excessive cytokine response. People with diabetes infected with SARS-CoV-2 have been observed to have much higher levels of interleukin-6 (IL-6) and C-reactive protein (CRP) than individuals without diabetes [25]. Penetration of SARS-CoV-2 into host cells induces an inflammatory response, repeated recruitment of T-helper cells, and production of interferon gamma, which lead to a cytokine storm [26]. For this reason, given the cellular mechanisms induced by COVID-19 and the pathophysiology of diabetes, people with diabetes are more susceptible to the occurrence of a cytokine storm with potential organ damage [27]. Deregulated glucose concentrations in the blood also affect the course of respiratory diseases and inflammatory states. A study in COVID-19 patients with pre-existing type 2 diabetes showed that people with a regulated glucose level in the blood fared better than those with poor control of glucose levels. Having a normalized blood glucose concentration (glycemic variability from 3.9 to $10.0 \mathrm{mmol} / \mathrm{L}$ ) was linked to fewer medical interventions, fewer cases of serious organ damage, and less mortality from all causes during hospitalization compared to patients with poorly controlled blood glucose concentrations (glycemic variability exceeding $10.0 \mathrm{mmol} / \mathrm{L}$ ) [28]. Another study showed that hospitalized patients with hyperglycemia treated with an insulin infusion had a lower risk of death from COVID-19 than patients who did not receive an insulin infusion, most likely due to a decrease in inflammatory mediators [29].

It should be stressed here that in the case of diabetes, irrespective of the treatment applied, diet plays an enormous role. Regardless most diets, not only in our households but also in hospital wards and care homes, contain large amounts of simple carbohydrates. A systematic review comparing low-carbohydrate diets with low-fat diets showed that the low-carbohydrate diets were more effective at achieving control of glycemia, and at reducing both the short-term and the long-term risk of cardiovascular disease in patients with type 2 diabetes [30]. There is strong evidence that limiting carbohydrates in the diet is a safe and effective means of achieving control of glycemia and weight loss, and of reducing the need for medication to treat type 2 diabetes. In 2018, Diabetes Australia issued a statement claiming that there is reliable evidence that limiting consumption of carbohydrates can be a safe and effective meanss of reducing blood glucose levels, reducing body weight, and managing the risk factors of heart disease, such as an elevated cholesterol level and hypertension [31]. Furthermore, the American Diabetes Association in 2019 and Diabetes Canada in 2020 came out in support of low-carbohydrate diets as a real option for improving glycemia and potentially reducing medication doses for people with type 2 diabetes $[32,33]$. Limiting carbohydrates in the diet is a simple and safe intervention that quickly improves control of glycemia and can be implemented alongside the usual treatment in a medical or home environment. Although the pathophysiology of COVID-19 is multifactorial, insulin resistance is one of the strongest risk factors influencing impairment of metabolic functions. Nutritional counselling should be implemented in order to minimize the risk of complications from COVID-19 [31,34].

A different problem is malnutrition, especially in older patients. It is both a short-term and a long-term prognostic factor of increased mortality. Nutrient deficiencies (overt or latent), generalized or pertaining to single nutrients, reduce the body's immunity and thus can increase the risk of illness following infection with SARS-CoV-2. Nearly all hospitalized patients, including those with COVID-19, have poor nutritional status upon admission [34,35]. Malnutrition in patients is confirmed by low levels of lymphocytes, prealbumin, and albumin [35]. It is worth noting here that albumin itself does not depend exclusively on nutrition, but is part of several nutritional screening indicators [36]. A low albumin level has been linked to higher mortality rates, and a low prealbumin level may indicate a risk factor for rapid-onset respiratory failure and the need for mechanical ventilation $[37,38]$. COVID-19 patients often have elevated levels of acute phase proteins and CRP, which indicate ongoing inflammation in the body $[39,40]$. This may result in restriction of food intake, which is another factor leading to malnutrition. An inadequate diet, inflamma- 
tion, and the resulting malnutrition impair the immune response in these patients, reducing their chances of fighting the infection and thus increasing mortality [41,42]. Moreover, patients with critical symptoms of COVID-19 are at higher risk of malnutrition due to the imbalance in energy intake and expenditure. Fever, mechanical ventilation, increased respiratory muscle work, and hypercatabolism increase the body's energy consumption. A similar effect is exerted by metabolic disorders, such as impaired glucose metabolism -an increased blood glucose level, decreased oxidation, increased glycolysis and glycogenesis, and also decreased tissue sensitivity to insulin. This state can be exacerbated by inadequate intake of nutrients due to appetite loss, shortness of breath, and impaired consciousness. In addition, enteral nutrition and/or antiviral drugs may result in gastrointestinal symptoms such as nausea, diarrhea, and vomiting [40]. Many hospitalized patients have comorbidities that may be associated with swallowing disorders. In the course of pneumonia itself, problems with swallowing may occur in the form of dysphagia of the mouth and throat, which can significantly reduce appetite. Dysphagia in patients with pneumonia is correlated with higher mortality and a poorer prognosis [43]. Therefore, these patients require rapid nutritional support in hospital conditions. Nutritional screening should be performed for each patient admitted to hospital (in both mild and severe stages of disease) [40]. One useful tool is the NRS 2002 (nutritional risk screening) scale [44]. A result of $\geq 3$ points indicates a nutritional risk requiring intervention. It is also important to repeat this type of examination regularly in order to monitor and control the nutritional status of patients and to assess the risk of dysphagia, especially in older patients. Where possible, nutrition by mouth is the best option [45]. The objective should be to maintain adequate intake of macronutrients and energy and meet the RDA for vitamins and minerals, because of their anti-inflammatory and antioxidant potential. If it is not possible to meet the requirements for protein and energy, patients should receive appropriately chosen oral dietary supplements $[40,45,46]$. However, these are not always well tolerated, and respiratory functions in patients may deteriorate during their use $[40,45,46]$. In that case, enteral or parenteral nutrition should be considered $[40,45]$. The choice of enteral feeding should be preceded by an assessment of choking risk. If the patient's nutritional requirements cannot be met in this manner, parenteral nutrition should be considered [45]. The protocol of one Italian hospital involves a somewhat different procedure for early nutritional support of patients with COVID-19, in which parenteral feeding is implemented and enteral nutrition is deliberately omitted. This was explained by the fact that the presence of a nasogastric tube could negatively impact the effectiveness of treatment supporting respiratory function. The following is a simplified scheme according to the "ESPEN guideline on clinical nutrition in the intensive care unit" (Figure 2) $[45,46]$. 


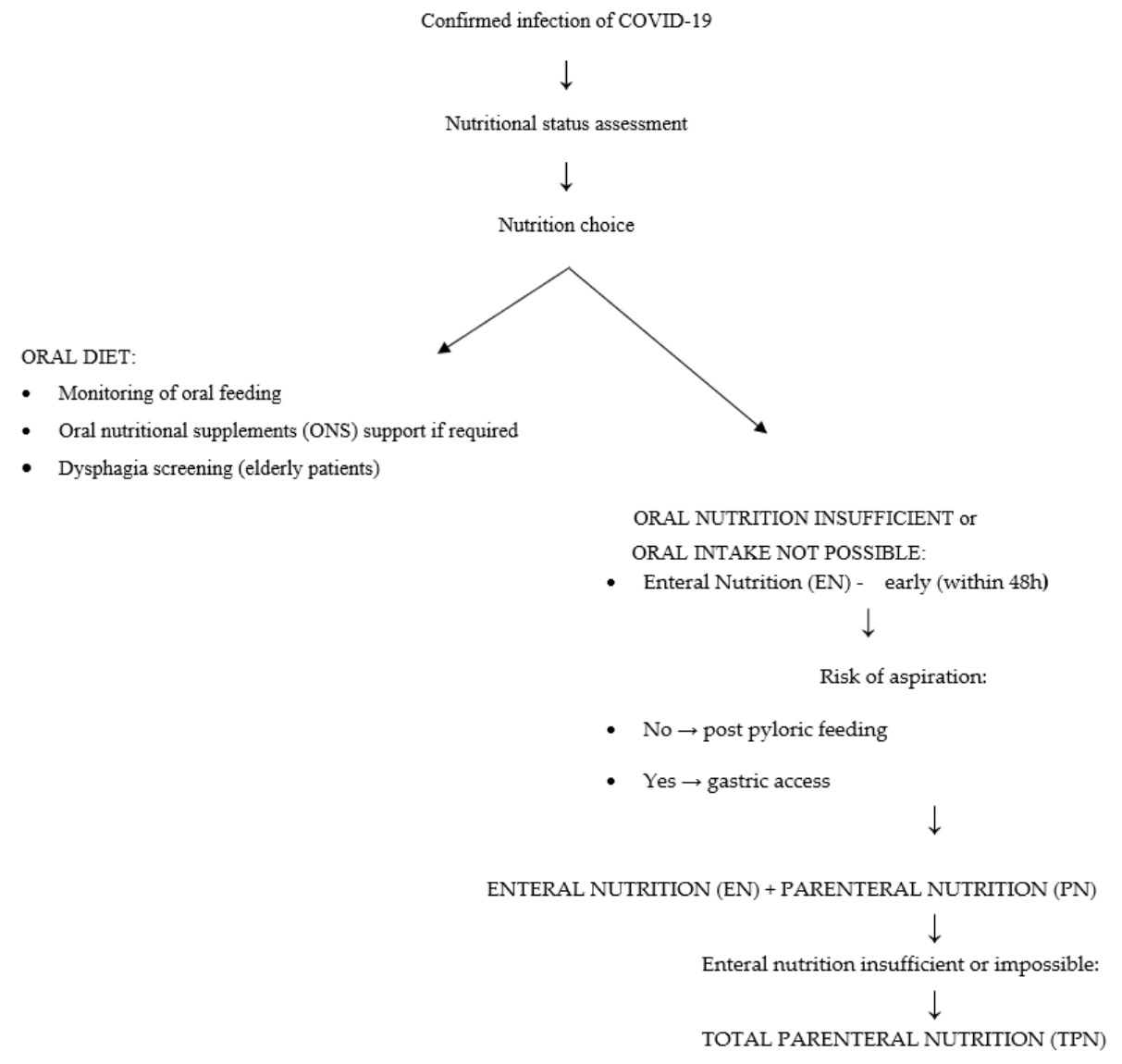

Figure 2. A diagram of dietary management in COVID-19 in hospital conditions. Modifications were based on the "ESPEN guideline on clinical nutrition in the intensive care unit [45]".

\section{Proposals for Specific Nutritional Requirements}

In a patient whose calorie intake is reduced by illness, it is recommended to achieve a target supply of energy as quickly as possible. According to ESPEN (European Society for Clinical Nutrition and Metabolism) guidelines, nutritional support should be initiated within $24-48 \mathrm{~h}$ after admission to hospital, beginning with a small dose of energy for the first few days $[45,47,48]$.

A meta-analysis carried out in patients in intensive care units (ICU) showed that early enteral nutrition within $24 \mathrm{~h}$ after admission to the ICU reduced mortality in patients compared to delayed nutrition [49]. In practice, resting energy expenditure (REE) can be calculated using a formula with the VCO2 measurement [47]. When it is not possible to directly measure $\mathrm{VCO} 2$, the energy requirement should be calculated according to body weight:

- $\quad$ for patients with normal body weight $\left(B M I=20-25 \mathrm{~kg} / \mathrm{m}^{2}\right)$ in critical condition, the recommended energy level is $25-30 \mathrm{kcal} /$ day $/ \mathrm{kg} \mathrm{BW}$.

- $\quad$ for overweight or obese patients $\left(B M I=25-30 \mathrm{~kg} / \mathrm{m}^{2}\right)$ in critical condition, the recommended energy level is $21 \mathrm{kcal} /$ day $/ \mathrm{kg} \mathrm{BW}$.

- for obese patients in critical condition, the recommended energy target is 11-14 kcal/ day $/ \mathrm{kg}$ BW for BMI $30-50 \mathrm{~kg} / \mathrm{m}^{2}$ and $22-25 \mathrm{kcal} /$ day $/ \mathrm{kg}$ BW for BMI $>50 \mathrm{~kg} / \mathrm{m}^{2}[47,50]$.

\section{Detailed Nutritional Strategies}

Nutritional treatment can be based on a multistage scheme [45,50,51]:

- Patients whose condition allows for oral nutrition. The patient should receive a traditional oral diet with an energy value of $25-30 \mathrm{kcal} / \mathrm{kg} /$ day and protein content of $1.2-2 \mathrm{~g} / \mathrm{kg} /$ day. The goal of the treatment is to meet $70 \%$ of the nutritional requirement 
within 3-7 days. Meals should be small, and if there is a choking risk a semi-liquid diet should be used. Nutritional education for the patient is recommended.

- Patients whose condition allows for oral nutrition, but with the risk that it will be inadequate. In addition to a traditional diet, the patient should receive oral nutritional supplements supplying 400-600 kcal. Increasing the amount of protein in the diet may reduce mortality. It is crucial to carefully monitor side effects, assess treatment effects, and dynamically adjust the treatment plan to the clinical course of COVID-19. Protein intake should be about $1.5-2.0 \mathrm{~g} / \mathrm{kg} \mathrm{BW} /$ day. When it does not meet the requirement, a standard protein preparation is recommended.

- Patients in critical condition, when oral nutrition is not possible and insertion of a nasogastric tube is required. Total enteral nutrition is implemented $(10-20 \mathrm{~mL} / \mathrm{h}$; $10-20 \mathrm{kcal} / \mathrm{h}$ ). The treatment goals are to prevent gastrointestinal complications during mechanical ventilation, stimulate intestinal immune function, and maintain intestinal barrier integrity and intestinal function.

- Patients in critical condition with a contraindication for enteral feeding, with no possibility of achieving an adequate energy level. Partial enteral nutrition and/or total parenteral nutrition should be implemented ( $<60 \%$ of energy; initially glucose in infusions of $5 \mathrm{mg} / \mathrm{kg} / \mathrm{min}$; fatty acids: infusion time $>8 \mathrm{~h}$ ). An 'all-in-one' solution is recommended.

\section{Food Components with Regard to Their Protective Effects in COVID-19 Patients}

Dietary strategies aimed at preventing COVID-19 and dangerous pneumonia are continually being considered. Unfortunately, as in the case of drugs, studies in humans have not confirmed any specific food components to be effective in the case of COVID-19. We know that the immune system is the key to reducing the severity of COVID-19, and perhaps by modulating it in the right way we can save human lives with preventive measures. Numerous clinical studies have shown that nutraceuticals can beneficially stimulate the immune response in patients with various diseases, such as cancer or AIDS, and in healthy people at risk of viral infections [52-55]. Natural compounds are commonly recognized as valuable agents in the fight against viruses due to their structural diversity and safety. Many products consumed by people and used in traditional medicine have been shown to contain substances with anti-inflammatory, antibacterial, and antiviral properties, e.g., vitamin C in the fruit or juice of raspberries or elderberries, hesperidin in St. John's wort, kaempferol and methylglyoxal in honey, allicin in garlic and onion, gingerols in ginger, curcumin in turmeric, and piperine in black pepper. However, there is no strong scientific evidence, nor are there any systematic literature reviews with meta-analyses indicating that herbs, spices, health-promoting food ingredients, or dietary supplements prevent infection with SARS-CoV-2, mitigate COVID-19 symptoms, or can even be used to treat infections, including severe "COVID pneumonia," acute lung failure, a "cytokine storm," clotting disorders, or multiple organ failure. Such connections can only be considered and hypothesized. Based on available in vitro evidence, greater understanding of the aggressiveness of COVID-19, and available data on other viruses, we present for consideration the following nutraceuticals and dietary strategies:

\subsection{Elderberry}

The elderberry (Sambucus nigra) may be useful against COVID-19 due to its capacity to stimulate the immune system and inhibit the replication of viruses, including human coronavirus NL63 (HCoV-NL63), which differs from COVID-19 but belongs to the same family of coronaviruses [56-59]. It could be especially helpful during the initial stage of coronavirus infection or for preventing infection. By inhibiting replication of the virus, elderberries significantly increase the production of pro-inflammatory cytokines (IL-1 $\beta$, TNF- $\alpha$, IL-6, and IL-8), especially TNF- $\alpha$, which enhances the response of macrophages to a viral infection [60-63]. A review by the Natural Standard Research Collaboration concluded that there is level B evidence in support of the use of elderberries to treat the 
flu [61], which may or may not be of significance for the prevention of COVID-19. The typical dose of 2:1 elderberry extract is $10-60 \mathrm{~mL}$ a day for adults and $5-30 \mathrm{~mL}$ a day for children.

\subsection{LC-PUFA}

The concept of the "cytokine storm" refers to a reaction of the body manifested by an inability to defeat the virus, so that it begins to produce vast amounts of antibodies, which attack its own cells and tissues, instead of fighting only the pathogen. It has even been compared to drowning in the water used to extinguish a fire. Undurti N. Das [64] showed that unsaturated omega- 3 and omega- 6 acids may regulate inflammation, whereas deficiencies in unsaturated fatty acids, mainly EPA and DHA, may increase one's susceptibility to viral diseases, including the novel coronavirus causing COVID-19. Omega-6 fatty acids are substrates for the production of pro-inflammatory prostaglandins and leukotrienes, which help the immune system to take control over invasion by pathogens [65]. The role of omega- 3 fatty acids is to inhibit pro-inflammatory processes and suppress the immune response, e.g., by promoting the proliferation of Treg cells and inhibiting activation of neutrophils and monocytes [65]. In a pilot study [66], the risk of death from COVID-19 for subjects with the lowest concentrations of omega- 3 fatty acids in the blood was four times as high as the risk for those with the highest concentrations. DHA and EPA exhibit strong anti-inflammatory activity, and both oral and intravenous intake of these acids may increase resistance to COVID-19 and improve the prognosis of infected patients. To reduce oxidative stress and the frequency of acute respiratory distress syndrome and sepsis, a mixture of fish fatty acids can be used: docosahexaenoic acid (DHA) + eicosapentaenoic acid (EPA) [48,50]. In the case of enteral feeding, $500 \mathrm{mg}$ EPA + DHA/day is recommended, and in the case of parenteral nutrition, from 0.1 to $0.2 \mathrm{~g}$ per $\mathrm{kg} /$ day [48].

\subsection{Selenium}

Selenium plays an important role in protecting the respiratory system, especially against viral infections [67]. Deficiencies of selenium in the diet can affect the immune response and the pathogenicity of the virus $[68,69]$. Administration of selenium in combination with CoQ10 decreases the non-specific inflammatory response and mortality from cardiovascular causes $[70,71]$. When administered with acetylcysteine, selenium helps to achieve a normal level of intracellular GSH (reduced glutathione), which is responsible for the optimal level of GPX (glutathione peroxidase-one of the strongest antioxidant selenoenzymes). The GPX mimetic ebselen (a synthetic selenium compound) is a strong inhibitor of the main SARS-CoV-2 protease [72,73]. The role of selenium in normal immune system function is linked to its antioxidant properties and its ability to increase the production of interleukin IL-2, which exhibits immunoregulatory properties; i.e., it stimulates or inhibits immune reactions depending on current needs [74,75]. In addition, the beneficial effect of appropriate selenium doses on the immune system is important in patients infected with SARS-Cov-2, because it modulates secretion of IL-6, which plays a key role in the pathophysiology of the disease [74]. Selenium administration is recommended at doses from 100 to $200 \mu \mathrm{g}$ a day [76].

\subsection{Vitamin D}

Vitamin D receptors are present in many immune cells and modulate the response to viral lung diseases. Vitamin $\mathrm{D}$ is thus a significant factor in protection against infectious respiratory diseases [77] and plays an important role in the prevention of COVID-19. Research has shown the infection rate to be higher in countries with higher latitudes and/or lower levels of vitamin D [78,79]. In another study, from Los Angeles, vitamin D deficiency was identified as a risk factor for positive COVID-19 tests [80]. The authors of a study from Cincinnati found links between vitamin D deficiency and hospitalization, disease severity, and death among patients in primary care and specialist clinics [81]. Severe vitamin D deficiency is often observed in patients in critical condition and seems to be linked to a 
poor prognosis [82]. It is associated with exacerbation of pneumonia, leading to acute respiratory distress syndrome with damage to the respiratory epithelium and hypoxia [82]. For prevention, long-term intake of vitamin D at dosages of $\leq 100 \mu \mathrm{g}$ D3/day is recommended [83]. Vitamin D stimulates and modulates the immune response and protects the upper and lower respiratory tract from viral infection $[84,85]$. Cholecalciferol exerts an immunomodulatory effect by differentiating monocytes into macrophages and increasing their chemotactic capacity and phagocytic capacity [86]. Vitamin D deficiency has been shown to expose people to a high risk of viral respiratory infection [87]. Furthermore, vitamin D modulates T cell function; stimulates the production of anti-inflammatory IL-10; and reduces the production of pro-inflammatory IL- $1 \beta$, IL-6, TNF- $\alpha$, RANKL, COX-2, and nitric oxide [88]. Based on the latest scientific reports, oral supplementation with vitamin $D$ may not only reduce the risk of SARS-CoV-2 infection, but also reduce mortality in patients with COVID-19 [89]. Recently published meta-analysis results indicate that the level of vitamin D does not affect the risk of infection, but that vitamin D deficiency is significantly linked to more severe disease and a higher risk of death [90]. Computer simulations were used to show that both forms of vitamin D (ergocalciferol and cholecalciferol), retinoids (vitamin A derivatives), and steroids "fit" the spike protein of the virus [91]. The SARS-CoV-2 spike protein has been shown to mediate entry into human cells by binding to the ACE2 receptor. People with high cholesterol levels be at greater risk of severe COVID-19 because cholesterol binds to the spike (S) protein in such a way that it exposes the ACE2-binding domain. Interestingly, vitamins A, D, and K, linolenic acid, and the drug dexamethasone bind to the $S$ protein at another site, thereby stabilizing its closed conformation. This means that the region of the protein responsible for binding to the ACE2 receptor is not exposed, and the risk of infection decreases. In obese people, the vitamin D concentration in the blood is reduced (deposited in adipose tissue), and as mentioned above, the risk of severe COVID-19 is greater.

In our discussion of vitamin $\mathrm{D}$, it should be borne in mind that the main source of all vitamins should be the diet. Among foods, the best source of vitamin $\mathrm{D}$ is fatty fish (on average $10 \mu \mathrm{g} / 100 \mathrm{~g}$ vs. $0.4 \mu \mathrm{g} / 100 \mathrm{~g}$ in the case of lean fish). Other products supplying vitamin D include eggs (on average $0.8 \mu \mathrm{g}$ in one egg), margarine, and blended spreadsto which the addition of vitamin D is mandatory in Poland (maximum $7.5 \mu \mathrm{g} / 100 \mathrm{~g}$ ). However, the effectiveness of the use of vitamin D for preventing and treating COVID-19 is still not fully known. The situation regarding scientific studies on this vitamin and coronavirus infection is highly dynamic, with new research papers appearing nearly every week. At the current stage of knowledge, although the apparent role of vitamin D in coronavirus infection has not been confirmed, it is believed that supplementation may have clinical benefits, but should only be implemented in controlled hospital conditions (for patients and medical personnel), to raise the concentration of vitamin $\mathrm{D}$ to exceed even $40 \mathrm{ng} / \mathrm{mL}$. Some papers have concluded by recommending a daily intake of 2000$4000 \mathrm{IU}$ of vitamin D to reach a concentration of $30 \mathrm{ng} / \mathrm{mL}$ to prevent infection, and stating that infected patients should be given a bolus dose (50,000-200,000 IU), after which the dose should be adjusted to maintain a concentration of $40-60 \mathrm{ng} / \mathrm{mL}$ of the vitamin in the blood [92-96]. Further studies, especially randomized trials, may provide specific practical solutions.

\subsection{Vegetables and Fruit}

According to well-known recommendations, half of one's daily diet should consist of vegetables and fruit. We should consume at least five portions of fruit and vegetables every day, predominantly vegetables (3-4 portions of vegetables and $1-2$ portions of fruit). Ideally, they should be of different colors and raw or minimally processed. This may be linked to a reduced risk of infection with SARS-CoV-2 due to the presence of antiviral and immunostimulatory compounds in these foods, particularly flavonoids. Many flavonoids have been shown to reduce signaling of the NLRP3 inflammasome in vitro, thereby reducing NFkB expression and indirectly expression of TNF- $\alpha$, IL-6, IL-1 $\beta$, and IL-18 [97]. Inflammasomes 
are a group of intracellular complexes contained in the cytosol and constituting an element of nonspecific immunity. They are responsible for detecting damage-associated molecular patterns (DAMP) and the presence of pathogens (pathogen-associated molecular patterns (PAMP)), and for the production of pro-inflammatory cytokines [98]. The mechanism of NF-kB activation has several steps. Normally, NF-kB is inactive and blocked by proteins inhibiting IkB. The virus activates NF-kB, causing degradation of IkB by IkB kinase (IKK); NF-kB enters the nucleus and induces DNA transcription. Once NF-kB has moved into the cell nucleus, the coronavirus causes it to bind to DNA and activate genes of the inflammatory response, causing a "cytokine storm" -i.e., overproduction of inflammatory cytokines (IL-1, IL-6, and TNF- $\alpha$ ), molecules (ICAM), and enzymes (COX-2) — which in turn leads to mass migration, infiltration, and accumulation of immune cells in lung tissues. This is followed by severe cellular hypoxia, which causes lung damage. Therefore, inhibition of NF-kB may be beneficial for controlling inflammatory states. Attempts can be made to block NF-kB naturally, using flavonoids such as the following.

Epigallocatechin gallate and its derivatives epigallocatechin, epicatechin gallate, and epicatechin, found in green tea, exhibit antiviral and anti-cancer properties. They most likely inhibit the early stages of infection, i.e., adhesion, penetration, and membrane fusion, by interfering with viral membrane proteins. To enhance the virucidal effect, i.e., the binding affinity of epigallocatechin gallate to viral particles, it is recommended to use an epigallocatechin gallate derivative and a fatty acid. The fatty acid on the phenolic hydroxyl group should increase the permeability of viruses and cell membranes [99-101].

Quercetin is present in ginkgo biloba, and in fruits and vegetables such as apples, berries, grapes, onions, shallots, and tomatoes $[102,103]$. In a clinical trial with patients with chronic systemic inflammation (CSI) in stable coronary artery disease (CAD), quercetin exhibited anti-inflammatory activity with decreased CSI indicators. Quercetin decreased gene expression and serum levels of IL- $1 \beta$, IL- 6 , IL-8, and TNF- $\alpha$, and the transcriptional activity of NF-kB in mononuclear blood cells. The doses in the trial ranged from 100 to $1000 \mathrm{mg}$ /day, but due to poor bioavailability (2-3\%), doses of $500-1000 \mathrm{mg} /$ day are recommended. It should be stressed that both quercetin and epigallocatechin gallate act as antioxidants and signaling molecules, and the functions of many enzymes activated by polyphenolic compounds depend on zinc. Flavonoids have also been shown to act as zinc ionophores, transporting zinc cations through the plasma membrane [104]. In theory, this could enhance the antiviral effects of zinc.

Baicalin and wogonoside are found in Chinese skullcap (Scutellaria baicalensis Georgi). Several studies have found very promising antiviral properties, including NF-kB inhibition. Moreover, baicalin exhibits virucidal activity against extracellular viral particles, which is important in minimizing the risk of severe disease [105,106].

Liquiritigenin, present in liquorice Glycyrrhiza glabra, inhibits the inflammatory response induced by an elevated glucose level, thereby reducing the expression and secretion of IL -6 and IL-1 $\beta$ in the mesangial cells of the renal glomeruli (HBZY-1). Likirytygenin has also been shown to inhibit activation of NF- $\mathrm{kB}$ inflammasome pathways induced by excess glucose [107]. Compounds contained in liquorice root can thus potentially inhibit viruses such as HIV-1, HCV, HSV, EBV, and coronaviruses.

Myricetin, which is found in tomatoes, oranges, nuts, and berries, inhibits the formation of the NLRP3 inflammasome, which plays a key role in the innate immune response and the pathogenesis of many inflammatory diseases. An in vivo study using murine models of sepsis induced by lipopolysaccharides (LPS) and alum-induced peritonitis showed that myricetin inhibits the formation of the NLRP3 inflammasome [108]. Moreover, due to the pleiotropic properties of myricetin (anti-inflammatory, antioxidant, autophagous, and reduction of the formation of amyloid plaques and tau protein phosphorylation), myricetin is a promising compound for the treatment of neurodegeneration of the brain caused by ischaemia and full-blown dementia [109].

Curcumin, found in Curcuma longa, is not well absorbed. Even high doses do not cause a significant increase in the serum level. However, administration together with 
piperine and fat increases its intestinal absorption. This substance has anti-inflammatory effects, suppressing cytokines and reducing expression of the enzymes COX-2 and iNOS. Curcumin also suppresses the production of pro-inflammatory cytokines TNF- $\alpha$, IL-1, IL-2, IL-6, IL-8, and IL-12 [110,111]. However, its best described anti-inflammatory mechanism of action is inhibition of NF-kB signaling. Curcumin has been shown to inhibit the degradation of IkB and subsequently the translocation of the protein p65 NF-kB to the nucleus. Curcumin also blocks the signal leading to activation of IKK [112].

Resveratrol (found in black, red, and green grapes, strawberries, raspberries, bilberries, cranberries, and currants) exhibits anti-inflammatory activity. In vitro studies have shown that resveratrol more effectively inhibits NF-kB than glucocorticosteroids or dexamethasone $[113,114]$. The anti-inflammatory properties of resveratrol have been shown to be strong enough to reduce expression of the enzyme COX-2, even following administration of a pro-inflammatory agent [114]. This effect is a reflection of the ability of resveratrol to inhibit NF-kB and thereby reduce pro-inflammatory gene expression $[115,116]$. Due to its ability to modulate platelet activation and aggregation, and factors associated with the coagulation cascade, resveratrol seems to be an attractive pharmacotherapeutic agent for the fight against COVID-19. It could be an auxiliary treatment and alleviate symptoms of thrombosis and systemic inflammation [116]. Elevated levels of circulating inflammatory cytokines are often associated with abnormal clotting parameters in patients with COVID-19. Although procedures with low-molecular-weight heparin (LMWH) have reduced mortality in patients with severe COVID-19, additional therapeutic strategies are needed. A possible alternative is the use of natural compounds to prevent and reduce risk factors associated with pre-existing conditions and comorbidities. Resveratrol, owing to its anticoagulant and anti-inflammatory properties, can be a promising adjuvant for the prevention and treatment of COVID-19.

\subsection{Vitamin C}

Vitamin $C$ takes part in physiological processes associated with immunity and in the blood clotting process, which is of importance in the course of COVID-19. In order for the body to defend itself against viruses, it must have an adequate level of vitamin C. Like flavonoids, ascorbic acid inhibits activation of the NLRP3 inflammasome [103]. Clinical trials have shown that vitamin $C$ reduces the frequency, duration, and severity of the common cold and the incidence of pneumonia. Typical daily doses of vitamin $C$ range from 500 to $3000 \mathrm{mg}$, and even higher doses are used in periods of acute infection. It is theoretically possible that vitamin C affects COVID-19 [117]. In a clinical trial, during infection with the Epstein-Barr virus (EBV), reduced levels of anti-EBV IgG and IgM antibodies were noted during intravenous vitamin $C$ treatment [118]. In the case of acute respiratory distress syndrome (ARDS) induced by rhinoviruses/enteroviruses in 2017, high-dose intravenous vitamin C (HDIVC) was associated with rapid resolution of lung damage [119]. Many studies have confirmed the beneficial effects of high doses of vitamin C to treat lung damage, alleviate severe sepsis, and reduce the durations of stays in intensive care units and of mechanical ventilation in ARDS patients [120-124]. Other meta-analyses, however, have not found that high-dose intravenous vitamin $C$ ( $6 \mathrm{~g} /$ day) improves the condition of patients with COVID-19 [125].

\subsection{Melatonin}

The use of melatonin can significantly reduce the levels of pro-inflammatory cytokines (TNF- $\alpha$, IL-1 $\beta$, IL-6, and IL-8) and increase the levels of anti-inflammatory cytokines, thereby stabilizing the work of the immune system [126]. Melatonin improves the proliferation and maturation of $\mathrm{T}$ and $\mathrm{B}$ lymphocytes, granulocytes, and monocytes. Melatonin produced in the lungs can be helpful for fighting SARS-CoV-2. It not only has strong preventive properties, but also inhibits the spread of the coronavirus in the body, according to the findings of researchers from the University of São Paulo (USP) [127]. Experts suggest that it could be used to produce a drug to treat COVID-19. Melatonin has been shown 
to inhibit NFkB activation and help to inhibit NLRP3 inflammasomes, which are linked to lung disease induced by infections. COVID-19 activates NLRP3s and enhances their effect, whereas melatonin reduces their expression levels and significantly decreases the penetration of macrophages and neutrophils into the lungs [128]. The reduction in melatonin production with age is one of the mechanisms explaining why children do not have severe symptoms as often as older people. Shorter sleep increases the risk of infection for many diseases. A lack of sleep, which is particularly important in the case of COVID-19, increases levels of the monokine CXCL9 induced by interferon, which increases lymphocyte infiltration and is involved in activation of the NLRP3 inflammasome [129]. Melatonin also reduces oxidative lung damage and recruitment of inflammatory cells during viral infections [126]. Typical doses of melatonin vary widely from 0.3 to $20 \mathrm{mg}$ (this last dose is applied in cancer treatments).

\subsection{Zinc}

Zinc takes part in regulating the inflammatory response by influencing the activity of leukocytes and lymphocytes, including their proliferation, differentiation, and maturation, and also has direct antiviral effects [130]. Coronaviruses seem to be susceptible to the antiviral activity of zinc. Zinc can prevent the coronavirus from entering cells and seems to reduce its virulence [131,132]. A deficiency of zinc causes dysfunctional humoral and cellular immunity [133]. In older people, a low Zn level (serum level $<0.7 \mathrm{mg} / \mathrm{l}$ ) has been shown to be a risk factor for pneumonia [134]. A long-term zinc deficiency exacerbates inflammation and biomarkers of the inflammatory state [135]. Combined administration of zinc and pyrithione, even in small concentrations, inhibited replication of the SARS coronavirus (SARS-CoV) in vitro by inhibiting the activity of RNA polymerase [136]. Consequently, zinc supplementation may influence not only the overactive inflammatory response associated with COVID-19, but possibly also SARS-CoV-2 itself [137]. In the long term, intake of $\leq 25 \mathrm{mg}$ /day is recommended, because high zinc intake can disturb the balance of copper. The typical daily dose of zinc is $15-30 \mathrm{mg}$ from lozenges, which directly protect the upper respiratory tract. Testing to determine the level of zinc prior to supplementation is essential [76].

\subsection{The Microbiome-Probiotics}

Given that SARS-CoV-2 has receptors in the intestinal endothelium, infection will reduce the expression of ACE2 in the gastrointestinal tract, and thus by various mechanisms may lead to intestinal dysbiosis [138]. The number of ACE-2 receptors in the duodenum increases with age, which suggests a potential entry mechanism for SARS-CoV-2 [139] and effects on its infectiousness and the severity of COVID-19 [140,141]. Research has detected the SARS-CoV-2 virus in anal swabs and stool samples in nearly $50 \%$ of patients with COVID-19, which suggests that the digestive tract may be an extrapulmonary site of replication and activity of the virus [6,142]. Moreover, an elevated level of calprotectin has been noted in the stool of COVID-19 patients with diarrhea, which is an indicator of the inflammatory response in the intestines [143]. During COVID-19 in patients in a severe/critical state of health, levels of pro-inflammatory cytokines IL-6, IL-10, IFN, and TNF- $\alpha$ are elevated [144]. Due to intestinal dysbiosis during COVID-19, the populations of commensal bacteria have been shown to be replaced by pathogenic species. For example, higher levels of Klebsiella, Streptococcus, and Ruminococcus gnavus in COVID-19 patients have been correlated with increases in the levels of pro-inflammatory cytokines (IFN- $\gamma$ and TNF- $\alpha$ ), leading to a cytokine storm and activation of T helper cells (Th1) [145]. Many opportunistic pathogens have been detected in stool samples from COVID-19 patients, including Streptococcus, Rothia, Veillonella, Erysipelato clostridium, Actinomyces, Enterococcus faecalis, Escherichia coli, and Klebsiella pneumoniae; and pro-inflammatory bacteria, such as Coprobacillus, Clostridium ramosum, Collinsella aerofaciens, Collinsella tanakaei, Streptococcus infantis, and Morganella morganii [140,146,147]. An altered composition of intestinal bacteria due to an intestinal infection can thus play a role in regulating 
our immune response during COVID-19, especially given that increased presence of Actinomyces viscosus of pulmonary origin has also been detected in the intestines [140]. The effect of the intestines on the immune system and the gut-brain axis itself can strongly influence the speed of recovery from COVID-19 [148]. Unfortunately, COVID-19 in the intestines can also have long-term health consequences, especially since the loss of useful microbes persists in most patients despite the removal of SARS-CoV-2, which suggests that SARS-CoV-2 infection and/or hospitalization may involve a long-term effect on the microbiome [140]. There is a need for further studies of the effects of SARS-CoV-2 on the intestinal microbiome during and after COVID-19. In particular, it is worth asking whether the use of probiotics would have health benefits. Probiotics are known to help to prevent gastrointestinal diseases, diarrhea following antibiotic treatment, sepsis, and respiratory tract infection (RTI) [149]. A randomized trial has also shown that in mechanically ventilated patients there are far fewer cases of pneumonia following administration of probiotics (Lactobacillus rhamnosus GG or live Bacillus subtilis) compared to controls [150]. It can be presumed that administration of probiotics would cause changes in the balance between Th1 and Th2 cells, and thus reduce the cytokine storm and severity of COVID-19 [151]. However, there is a concern about the possibility of opportunistic pathogen infections, especially in people with comorbidities such as cancer, leaky gut syndrome, or diabetes, and in organ transplant recipients [152]. Some probiotic strains take advantage of weakened immunity to transform into opportunistic pathogens, causing acute pneumonia, endocarditis, or sepsis [141]. There is a need for studies encompassing the effects of both diet and probiotics on the severity of COVID-19.

\section{General Principles-Nutritional Prophylaxis}

Obesity and the chronic diseases associated with it (diabetes, metabolic syndrome, and cardiovascular disease) can predispose patients to a more severe course of COVID19 [153-155]. This is linked to chronic inflammation and the associated production of mediators, immune dysregulation, oxidative stress, endothelial dysfunction, and equally importantly-increased expression of the above-mentioned ACE2 [154-156]. There are also data indicating that adipose tissue is a storage site for viruses. All of these factors can contribute to poorer COVID-19 treatment results and reduce survival rates [157]. The adoption of good nutritional habits and a healthy, balanced diet are well known to be extremely important for preventing and treating obesity. Unfortunately, the COVID-19 pandemic has led to a profound change in eating behavior, even among inhabitants of Mediterranean countries, whose diets are regarded as models of good nutrition. Isolation at home has often been associated with the accumulation of non-perishable, highly processed food products and more difficult access to fresh food. In addition, many people have stopped exercising and begun to lead sedentary lifestyles [31]. The optimal nutritional model is still considered to be the Mediterranean diet or the similar DASH diet [158-160]. They can prevent obesity and are thus effective in preventing a more critical course of COVID-19. These diets are based on fresh, unprocessed plant-based foods, such as vegetables (including the seeds of legumes), fruit, and wholemeal products [158]. The plant products (fruit, vegetables, nuts, and olive oil) constituting the basis of the Mediterranean diet are a significant source of bioactive polyphenolic compounds. These compounds, especially flavonoids and their metabolites, exhibit pleiotropic health-promoting effects, especially in cardiovascular and metabolic disorders $[159,160]$. Owing to their antioxidant, anti-inflammatory, and anticoagulant properties, they are becoming even more important in the face of the severe inflammatory and prothrombotic state associated with COVID-19 [161,162]. They mitigate the immune response, increase antioxidant defense, improve vascular reactivity, and reduce tissue inflammation and cell infiltration. They appear to exert these beneficial effects by preventing activation of the NF- $\mathrm{KB}$ and NADPH signaling pathways and by lowering the levels of IL- 6 and TNF- $\alpha[163,164]$. In addition, the ellagic acid contained in some fruits and nuts exerts effects through interaction with the microbiota and epigenetic regulation [159]. Therefore, attempts to exploit the protective effects of flavonoids or other 
phytochemicals in the treatment of COVID-19 are extremely important [163]. In nutritional "anti-covid" prophylaxis, it is recommended to limit consumption of meat and animal fats, in order to reduce intake of saturated fats conducive to the development of low-grade inflammation [165]. Foods that should be incorporated in the diet include reduced-fat dairy products, vegetable fats (except for tropical fats—coconut and palm oil), and fish fat, which contains unsaturated fatty acids with proven immunomodulatory effects [166]. N-3 polyunsaturated fatty acids in seafood (shellfish, algae, and fish) and flax seeds support the immune system by activating both specific and nonspecific immune mechanisms [167]. N-9 monounsaturated fatty acids, present in olive oil and nuts, have antioxidant, antibacterial, and antiviral effects [168]. Experts also suggest avoiding salt and replacing it with herbs and spices. It is also recommended to exclude excessive amounts of sugar, ubiquitous in sweetened beverages, sweets, and highly processed foods. In the context of COVID-19, the roles of minerals such as zinc and vitamins $\mathrm{C}, \mathrm{D}$, and A are emphasized, as is adequate hydration of the body [158]. In addition, in considering the effect of diet on the body in a state of illness, we must not forget our mental health needs. Constant stress disrupts immune regulation and is associated with increased levels of pro-inflammatory cytokines, such as IL-6 [169]. Severe stress in mice has been shown to increase IL-1 $\beta$ by activating the NLRP3 inflammasome [170]. Various techniques, such as meditation, breathing exercises, and visualization, can be helpful for reducing stress and the levels of inflammatory cytokines.

\section{Conclusions}

Advanced age and comorbidities such as cardiovascular disease, diabetes, chronic respiratory diseases, obesity, hypertension, and cancer are linked to higher mortality from pneumonia induced by COVID-19. A healthy, well-balanced diet has a beneficial effect on these conditions that predispose one to COVID-19 and its consequences. A diet with high antioxidant, anti-inflammatory, and immunomodulatory potential may constitute prophylaxis mitigating the severity of COVID-19. For this reason, there is a need for more studies to determine the potential of specific diet components to prevent COVID-19 and improve parameters of infection during illness. In the case of COVID-19 patients that are hospitalized, in critical condition, and in intensive care units, it is recommended to assess their nutritional status and implement rapid and appropriate nutritional care. Nutritional support should include adequate intake of all nutrients - especially proteins, n-3 fatty acids, microelements (selenium and zinc), and vitamins, especially D and C - and a caloric value adjusted to the patient's needs.

Author Contributions: Conceptualization, D.S.; writing-original draft preparation, M.B., S.K., M.M., and N.M.; writing-review and editing, D.S. and B.B.-K. All authors have read and agreed to the published version of the manuscript.

Funding: This research received no external funding.

Institutional Review Board Statement: Not applicable.

Informed Consent Statement: Not applicable.

Conflicts of Interest: The authors declare no conflict of interest.

\section{References}

1. WHO. Coronavirus Disease (COVID-19)—World Health Organization. Available online: https://www.who.int/publications/m/ item/weekly-epidemiological-update-on-covid-19---3-august-2021 (accessed on 3 August 2021).

2. Lu, R.; Zhao, X.; Li, J.; Niu, P.; Yang, B.; Wu, H.; Wang, W.; Song, H.; Huang, B.; Zhu, N.; et al. Genomic Characterisation and Epidemiology of 2019 Novel Coronavirus: Implications for Virus Origins and Receptor Binding. Lancet 2020, 395, 565-574. [CrossRef]

3. Van Doremalen, N.; Bushmaker, T.; Morris, D.H.; Holbrook, M.G.; Gamble, A.; Williamson, B.N.; Tamin, A.; Harcourt, J.L.; Thornburg, N.J.; Gerber, S.I.; et al. Aerosol and Surface Stability of SARS-CoV-2 as Compared with SARS-CoV-1. N. Engl. J. Med. 2020, 382, 1564-1567. [CrossRef] [PubMed] 
4. English: 3D Medical Animation Still Shot Showing the Structure of a Coronavirus. 2020. Available online: https://www. Scientificanimations.Com/Coronavirus-Symptoms-and-Prevention-Explained-through-Medical-Animation/ (accessed on 3 August 2021).

5. Fehr, A.R.; Perlman, S. Coronaviruses: An Overview of Their Replication and Pathogenesis. Methods Mol. Biol. 2015, 1282, 1-23. [CrossRef] [PubMed]

6. Wölfel, R.; Corman, V.M.; Guggemos, W.; Seilmaier, M.; Zange, S.; Müller, M.A.; Niemeyer, D.; Jones, T.C.; Vollmar, P.; Rothe, C.; et al. Virological Assessment of Hospitalized Patients with COVID-2019. Nature 2020, 581, 465-469. [CrossRef]

7. Conti, P.; Ronconi, G.; Caraffa, A.; Gallenga, C.; Ross, R.; Frydas, I.; Kritas, S. Induction of Pro-Inflammatory Cytokines (IL-1 and IL-6) and Lung Inflammation by Coronavirus-19 (COVI-19 or SARS-CoV-2): Anti-Inflammatory Strategies. J. Biol. Regul. Homeost. Agents 2020, 34, 327-331. [CrossRef] [PubMed]

8. Cascella, M.; Rajnik, M.; Aleem, A.; Dulebohn, S.C.; Di Napoli, R. Features, Evaluation, and Treatment of Coronavirus (COVID-19). In StatPearls; StatPearls Publishing: Treasure Island, FL, USA, 2021.

9. Gheblawi, M.; Wang, K.; Viveiros, A.; Nguyen, Q.; Zhong, J.; Turner, A.J.; Raizada, M.K.; Grant, M.B.; Oudit, G.Y. AngiotensinConverting Enzyme 2: SARS-CoV-2 Receptor and Regulator of the Renin-Angiotensin System: Celebrating the 20th Anniversary of the Discovery of ACE2-PubMed. Circ. Res. 2020, 126, 1456-1474. Available online: https://pubmed.ncbi.nlm.nih.gov/32264791/ (accessed on 19 April 2021). [CrossRef] [PubMed]

10. Turgut, S.; Turgut, G.; Atalay, E.Ö.; Atalay, A. Angiotensin-Converting Enzyme I/D Polymorphism in Behçet's Disease. Med. Princ. Pract. 2005, 14, 213-216. [CrossRef]

11. Schüler, R.; Osterhoff, M.A.; Frahnow, T.; Seltmann, A.; Busjahn, A.; Kabisch, S.; Xu, L.; Mosig, A.S.; Spranger, J.; Möhlig, M.; et al. High-Saturated-Fat Diet Increases Circulating Angiotensin-Converting Enzyme, Which Is Enhanced by the Rs4343 Polymorphism Defining Persons at Risk of Nutrient-Dependent Increases of Blood Pressure. J. Am. Heart Assoc. 2017, 6, 1-11. [CrossRef] [PubMed]

12. People at Higher Risk from Coronavirus (COVID-19). Available online: https://www.nhs.uk/conditions/coronavirus-covid-19 /people-at-higher-risk/ (accessed on 13 June 2021).

13. Suratt, P.M.; Wilhoit, S.C.; Hsiao, H.S.; Atkinson, R.L.; Rochester, D.F. Compliance of Chest Wall in Obese Subjects. J. Appl. Physiol. 1984, 57, 403-407. [CrossRef] [PubMed]

14. Rimensberger, P.C.; Pristine, G.; Mullen, J.B.; Cox, P.N.; Slutsky, A.S. Lung Recruitment during Small Tidal Volume Ventilation Allows Minimal Positive End-Expiratory Pressure without Augmenting Lung Injury. Crit. Care Med. 1999, 27, 1940-1945. [CrossRef] [PubMed]

15. Stokes, E.K. Coronavirus Disease 2019 Case Surveillance-United States, January 22-May 30, 2020. MMWR Morb. Mortal. Wkly. Rep. 2020, 69, 759-765. [CrossRef] [PubMed]

16. Obesity and COVID-19: Policy Statement. Available online: https://www.worldobesity.org/news/obesity-and-covid-19-policystatement (accessed on 26 May 2021).

17. Kassi, E.; Pervanidou, P.; Kaltsas, G.; Chrousos, G. Metabolic Syndrome: Definitions and Controversies. BMC Med. 2011, 9, 48. [CrossRef] [PubMed]

18. Alberti, K.G.M.M.; Eckel Robert, H.; Grundy Scott, M.; Zimmet Paul, Z.; Cleeman James, I.; Donato Karen, A.; Jean-Charles, F.; James, W.P.T.; Loria Catherine, M.; Smith Sidney, C. Harmonizing the Metabolic Syndrome. Circulation 2009, 120, 1640-1645. [CrossRef]

19. Davenport, C.; Finucane, F.M. Coronavirus and Obesity: Could Insulin Resistance Mediate the Severity of Covid-19 Infection? Front. Public Health 2020, 8, 184. [CrossRef]

20. Hamming, I.; Timens, W.; Bulthuis, M.L.C.; Lely, A.T.; Navis, G.J.; van Goor, H. Tissue Distribution of ACE2 Protein, the Functional Receptor for SARS Coronavirus. A First Step in Understanding SARS Pathogenesis. J. Pathol. 2004, 203, 631-637. [CrossRef]

21. Kuba, K.; Imai, Y.; Rao, S.; Gao, H.; Guo, F.; Guan, B.; Huan, Y.; Yang, P.; Zhang, Y.; Deng, W.; et al. A Crucial Role of Angiotensin Converting Enzyme 2 (ACE2) in SARS Coronavirus-Induced Lung Injury. Nat. Med. 2005, 11, 875-879. [CrossRef]

22. Dominici, F.P.; Burghi, V.; Muñoz, M.C.; Giani, J.F. Modulation of the Action of Insulin by Angiotensin-(1-7). Clin. Sci. 2014, 126, 613-630. [CrossRef]

23. Takeda, M.; Yamamoto, K.; Takemura, Y.; Takeshita, H.; Hongyo, K.; Kawai, T.; Hanasaki-Yamamoto, H.; Oguro, R.; Takami, Y.; Tatara, Y.; et al. Loss of ACE2 Exaggerates High-Calorie Diet-Induced Insulin Resistance by Reduction of GLUT4 in Mice. Diabetes 2013, 62, 223-233. [CrossRef]

24. Jafar, N.; Edriss, H.; Nugent, K. The Effect of Short-Term Hyperglycemia on the Innate Immune System. Am. J. Med. Sci. 2016, 351, 201-211. [CrossRef]

25. Guo, W.; Li, M.; Dong, Y.; Zhou, H.; Zhang, Z.; Tian, C.; Qin, R.; Wang, H.; Shen, Y.; Du, K.; et al. Diabetes Is a Risk Factor for the Progression and Prognosis of COVID-19. Diabetes Metab. Res. Rev. 2020, 36, e3319. [CrossRef]

26. Singh, A.K.; Gupta, R.; Ghosh, A.; Misra, A. Diabetes in COVID-19: Prevalence, Pathophysiology, Prognosis and Practical Considerations. Diabetes Metab. Syndr. 2020, 14, 303-310. [CrossRef] [PubMed]

27. Cuschieri, S.; Grech, S. COVID-19 and Diabetes: The Why, the What and the How. J. Diabetes Complicat. 2020, $34,107637$. [CrossRef] [PubMed] 
28. Zhu, L.; She, Z.-G.; Cheng, X.; Qin, J.-J.; Zhang, X.-J.; Cai, J.; Lei, F.; Wang, H.; Xie, J.; Wang, W.; et al. Association of Blood Glucose Control and Outcomes in Patients with COVID-19 and Pre-Existing Type 2 Diabetes. Cell Metab. 2020, 31, 1068-1077.e3. [CrossRef] [PubMed]

29. Sardu, C.; D'Onofrio, N.; Balestrieri, M.L.; Barbieri, M.; Rizzo, M.R.; Messina, V.; Maggi, P.; Coppola, N.; Paolisso, G.; Marfella, R. Outcomes in Patients With Hyperglycemia Affected by COVID-19: Can We Do More on Glycemic Control? Diabetes Care 2020, 43, 1408-1415. [CrossRef]

30. van Zuuren, E.J.; Fedorowicz, Z.; Kuijpers, T.; Pijl, H. Effects of Low-Carbohydrate- Compared with Low-Fat-Diet Interventions on Metabolic Control in People with Type 2 Diabetes: A Systematic Review Including GRADE Assessments. Am. J. Clin. Nutr. 2018, 108, 300-331. [CrossRef] [PubMed]

31. Demasi, M. COVID-19 and Metabolic Syndrome: Could Diet Be the Key? BMJ Evid.-Based Med. 2021, 26, 1-2. [CrossRef]

32. Diabetes Canada. Position Statement on Low-Carbohydrate Diets for Adults with Diabetes: A Rapid Review. Can. J. Diabetes 2020, 44, 295-299. [CrossRef]

33. Evert, A.B.; Dennison, M.; Gardner, C.D.; Garvey, W.T.; Lau, K.H.K.; MacLeod, J.; Mitri, J.; Pereira, R.F.; Rawlings, K.; Robinson, S.; et al. Nutrition Therapy for Adults with Diabetes or Prediabetes: A Consensus Report. Diabetes Care 2019, 42, 731-754. [CrossRef] [PubMed]

34. Yeo, H.J.; Byun, K.S.; Han, J.; Kim, J.H.; Lee, S.E.; Yoon, S.H.; Jeon, D.; Kim, Y.S.; Cho, W.H. Prognostic Significance of Malnutrition for Long-Term Mortality in Community-Acquiredpneumonia: A Propensity Score Matched Analysis. Korean J. Intern. Med. 2019, 34, 841-849. [CrossRef]

35. Laviano, A.; Koverech, A.; Zanetti, M. Nutrition Support in the Time of SARS-CoV-2 (COVID-19). Nutrition 2020, 74, 110834. [CrossRef]

36. Keller, U. Nutritional Laboratory Markers in Malnutrition. J. Clin. Med. 2019, 8, 775. [CrossRef]

37. Holter, J.C.; Ueland, T.; Jenum, P.A.; Müller, F.; Brunborg, C.; Frøland, S.S.; Aukrust, P.; Husebye, E.; Heggelund, L. Risk Factors for Long-Term Mortality after Hospitalization for Community-Acquired Pneumonia: A 5-Year Prospective Follow-Up Study. PLoS ONE 2016, 11, e0148741. [CrossRef] [PubMed]

38. Wu, C.; Chen, X.; Cai, Y.; Xia, J.; Zhou, X.; Xu, S.; Huang, H.; Zhang, L.; Zhou, X.; Du, C.; et al. Risk Factors Associated with Acute Respiratory Distress Syndrome and Death in Patients With Coronavirus Disease 2019 Pneumonia in Wuhan, China. JAMA Intern. Med. 2020, 180, 934-943. [CrossRef] [PubMed]

39. Liu, W.; Tao, Z.-W.; Wang, L.; Yuan, M.-L.; Liu, K.; Zhou, L.; Wei, S.; Deng, Y.; Liu, J.; Liu, H.-G.; et al. Analysis of Factors Associated with Disease Outcomes in Hospitalized Patients with 2019 Novel Coronavirus Disease. Chin. Med. J. 2020, 133, 1032-1038. [CrossRef]

40. Stachowska, E.; Folwarski, M.; Jamioł-Milc, D.; Maciejewska, D.; Skonieczna-Żydecka, K. Nutritional Support in Coronavirus 2019 Disease. Medicina 2020, 56, 289. [CrossRef]

41. Lomax, A.R.; Calder, P.C. Prebiotics, Immune Function, Infection and Inflammation: A Review of the Evidence. Br. J. Nutr. 2009, 101, 633-658. [CrossRef]

42. Yaqoob, P. Ageing Alters the Impact of Nutrition on Immune Function. Proc. Nutr. Soc. 2017, 76, 347-351. [CrossRef]

43. Cabre, M.; Serra-Prat, M.; Palomera, E.; Almirall, J.; Pallares, R.; Clave, P. Prevalence and Prognostic Implications of Dysphagia in Elderly Patients with Pneumonia. Age Ageing 2010, 39, 39-45. [CrossRef] [PubMed]

44. Kondrup, J.; Rasmussen, H.H.; Hamberg, O.; Stanga, Z.; Ad Hoc ESPEN Working Group. Nutritional Risk Screening (NRS 2002): A New Method Based on an Analysis of Controlled Clinical Trials. Clin. Nutr. 2003, 22, 321-336. [CrossRef]

45. Singer, P.; Blaser, A.R.; Berger, M.M.; Alhazzani, W.; Calder, P.C.; Casaer, M.P.; Hiesmayr, M.; Mayer, K.; Montejo, J.C.; Pichard, C.; et al. ESPEN Guideline on Clinical Nutrition in the Intensive Care Unit. Clin. Nutr. 2019, 38, 48-79. [CrossRef] [PubMed]

46. Caccialanza, R.; Laviano, A.; Lobascio, F.; Montagna, E.; Bruno, R.; Ludovisi, S.; Corsico, A.G.; Di Sabatino, A.; Belliato, M.; Calvi, M.; et al. Early Nutritional Supplementation in Non-Critically Ill Patients Hospitalized for the 2019 Novel Coronavirus Disease (COVID-19): Rationale and Feasibility of a Shared Pragmatic Protocol. Nutrition 2020, 74, 110835. [CrossRef] [PubMed]

47. Singer, P. Simple equations for complex physiology: Can we use $\mathrm{VCO}_{2}$ for calculating energy expenditure? Crit Care 2016, 20 , 72 . [CrossRef] [PubMed]

48. Reignier, J.; Darmon, M.; Sonneville, R.; Borel, A.-L.; Garrouste-Orgeas, M.; Ruckly, S.; Souweine, B.; Dumenil, A.-S.; Haouache, H.; Adrie, C.; et al. Impact of Early Nutrition and Feeding Route on Outcomes of Mechanically Ventilated Patients with Shock: A Post Hoc Marginal Structural Model Study. Intensive Care Med. 2015, 41, 875-886. [CrossRef]

49. Li, X.Y.; Wang, Y.S.; Kang, H.Y.J.; Wang, F.; Sun, B.; Qiu, H.B.; Tong, Z.H. The Keypoints in Treatment of the Critical Coronavirus Disease 2019 Patient(2)—PubMed. Chin. J. Tuberc. Respir. Dis. 2020, 43, E26. Available online: https://pubmed.ncbi.nlm.nih.gov/ 32294811/ (accessed on 15 April 2021).

50. Dickerson, R.N.; Medling, T.L.; Maish, G.O.; Croce, M.A.; Minard, G.; Brown, R.O. Hypocaloric, high-protein nutritiontherapy in older vs younger critically ill patients with obesity. J. Parenter. Enter. Nutr. 2013, 37, 342-351. [CrossRef]

51. Ferrie, S.; Allman-Farinelli, M.; Daley, M.; Smith, K. Protein Requirements in the Critically Ill: A Randomized Controlled Trial Using Parenteral Nutrition. J. Parenter. Enter. Nutr. 2016, 40, 795-805. [CrossRef] 
52. Harvie, M. Nutritional Supplements and Cancer: Potential Benefits and Proven Harms. In American Society of Clinical Oncology Educational Book, Proceedings of the American Society of Clinical Oncology Annual Meeting, Chicago, IL, USA, 30 May-3 June 2014; American Society of Clinical Oncology: Alexandria, VA, USA, 2014; pp. e478-e486. [CrossRef]

53. D'Angelo, C.; Reale, M.; Costantini, E. Microbiota and Probiotics in Health and HIV Infection. Nutrients 2017, 9, 615. [CrossRef]

54. Miller, L.E.; Lehtoranta, L.; Lehtinen, M.J. Short-Term Probiotic Supplementation Enhances Cellular Immune Function in Healthy Elderly: Systematic Review and Meta-Analysis of Controlled Studies. Nutr. Res. 2019, 64, 1-8. [CrossRef]

55. Della Volpe, A.; Ricci, G.; Ralli, M.; Gambacorta, V.; De Lucia, A.; Minni, A.; Pirozzi, C.; Paccone, M.; Pastore, V.; Di Stadio, A. The Effects of Oral Supplements with Sambucus nigra, Zinc, Tyndallized Lactobacillus acidophilus (HA122), Arabinogalactans, Vitamin D, Vitamin E and Vitamin C in Otitis Media with Effusion in Children: A Randomized Controlled Trial. Eur. Rev. Med. Pharmacol. Sci. 2019, 23, 6360-6370. [CrossRef] [PubMed]

56. Weng, J.-R.; Lin, C.-S.; Lai, H.-C.; Lin, Y.-P.; Wang, C.-Y.; Tsai, Y.-C.; Wu, K.-C.; Huang, S.-H.; Lin, C.-W. Antiviral Activity of Sambucus FormosanaNakai Ethanol Extract and Related Phenolic Acid Constituents against Human Coronavirus NL63. Virus Res. 2019, 273, 197767. [CrossRef] [PubMed]

57. Porter, R.S.; Bode, R.F. A Review of the Antiviral Properties of Black Elder (Sambucus nigra L.) Products. Phytother. Res. PTR 2017, 31, 533-554. [CrossRef]

58. Chen, C.; Zuckerman, D.M.; Brantley, S.; Sharpe, M.; Childress, K.; Hoiczyk, E.; Pendleton, A.R. Sambucus Nigra Extracts Inhibit Infectious Bronchitis Virus at an Early Point during Replication. BMC Vet. Res. 2014, 10, 24. [CrossRef] [PubMed]

59. Hawkins, J.; Baker, C.; Cherry, L.; Dunne, E. Black Elderberry (Sambucus nigra) Supplementation Effectively Treats Upper Respiratory Symptoms: A Meta-Analysis of Randomized, Controlled Clinical Trials. Complement. Ther. Med. 2019, 42, 361-365. [CrossRef] [PubMed]

60. Barak, V.; Halperin, T.; Kalickman, I. The Effect of Sambucol, a Black Elderberry-Based, Natural Product, on the Production of Human Cytokines: I. Inflammatory Cytokines. Eur. Cytokine Netw. 2001, 12, 290-296.

61. Ulbricht, C.; Basch, E.; Cheung, L.; Goldberg, H.; Hammerness, P.; Isaac, R.; Khalsa, K.P.S.; Romm, A.; Rychlik, I.; Varghese, M.; et al. An Evidence-Based Systematic Review of Elderberry and Elderflower (Sambucus nigra) by the Natural Standard Research Collaboration. J. Diet. Suppl. 2014, 11, 80-120. [CrossRef] [PubMed]

62. Parameswaran, N.; Patial, S. Tumor Necrosis Factor- $\alpha$ Signaling in Macrophages. Crit. Rev. Eukaryot. Gene Expr. 2010, 20, 87-103. [CrossRef]

63. Akram, M.; Tahir, I.M.; Shah, S.M.A.; Mahmood, Z.; Altaf, A.; Ahmad, K.; Munir, N.; Daniyal, M.; Nasir, S.; Mehboob, H. Antiviral Potential of Medicinal Plants against HIV, HSV, Influenza, Hepatitis, and Coxsackievirus: A Systematic Review. Phytother. Res. PTR 2018, 32, 811-822. [CrossRef]

64. Das, U.N. Can Bioactive Lipids Inactivate Coronavirus (COVID-19)? Arch. Med. Res. 2020, 51, 282-286. [CrossRef]

65. Radzikowska, U.; Rinaldi, A.O.; Çelebi Sözener, Z.; Karaguzel, D.; Wojcik, M.; Cypryk, K.; Akdis, M.; Akdis, C.A.; Sokolowska, M. The Influence of Dietary Fatty Acids on Immune Responses. Nutrients 2019, 11, 2990. [CrossRef]

66. Asher, A.; Tintle, N.L.; Myers, M.; Lockshon, L.; Bacareza, H.; Harris, W.S. Blood Omega-3 Fatty Acids and Death from COVID-19: A Pilot Study. Prostaglandins Leukot. Essent. Fatty Acids 2021, 166, 102250. [CrossRef]

67. Avery, J.; Hoffmann, P. Selenium, Selenoproteins, and Immunity. Nutrients 2018, 10, 1203. [CrossRef] [PubMed]

68. Zhang, J.; Taylor, E.W.; Bennett, K.; Saad, R.; Rayman, M.P. Association between Regional Selenium Status and Reported Outcome of COVID-19 Cases in China. Am. J. Clin. Nutr. 2020, 111, 1297-1299. [CrossRef]

69. Moghaddam, A.; Heller, R.A.; Sun, Q.; Seelig, J.; Cherkezov, A.; Seibert, L.; Hackler, J.; Seemann, P.; Diegmann, J.; Pilz, M.; et al. Selenium Deficiency Is Associated with Mortality Risk from COVID-19. Nutrients 2020, 12, 2098. [CrossRef] [PubMed]

70. Alehagen, U.; Lindahl, T.L.; Aaseth, J.; Svensson, E.; Johansson, P. Levels of SP-Selectin and Hs-CRP Decrease with Dietary Intervention with Selenium and Coenzyme Q10 Combined: A Secondary Analysis of a Randomized Clinical Trial. PLoS ONE 2015, 10, e0137680. [CrossRef]

71. Alehagen, U.; Alexander, J.; Aaseth, J. Supplementation with Selenium and Coenzyme Q10 Reduces Cardiovascular Mortality in Elderly with Low Selenium Status. A Secondary Analysis of a Randomised Clinical Trial. PLoS ONE 2016, 11, e0157541. [CrossRef]

72. Sies, H.; Parnham, M.J. Potential Therapeutic Use of Ebselen for COVID-19 and Other Respiratory Viral Infections-PubMed. Free Radic. Biol. Med. 2021, 156, 107-112. Available online: https://pubmed.ncbi.nlm.nih.gov/32598985/ (accessed on 16 April 2021). [CrossRef]

73. Khomich, O.; Kochetkov, S.; Bartosch, B.; Ivanov, A. Redox Biology of Respiratory Viral Infections. Viruses 2018, 10, 392. [CrossRef]

74. Mahmoodpoor, A.; Hamishehkar, H.; Shadvar, K.; Ostadi, Z.; Sanaie, S.; Saghaleini, S.H.; Nader, N.D. The Effect of Intravenous Selenium on Oxidative Stress in Critically Ill Patients with Acute Respiratory Distress Syndrome. Immunol. Investig. 2019, 48, 147-159. [CrossRef] [PubMed]

75. Zheng, D.; Liwinski, T.; Elinav, E. Interaction between Microbiota and Immunity in Health and Disease. Cell Res. 2020, 30, $492-506$. [CrossRef] [PubMed]

76. Alexander, J.; Tinkov, A.; Strand, T.A.; Alehagen, U.; Skalny, A.; Aaset, J. Early Nutritional Interventions with Zinc, Selenium and Vitamin D for Raising Anti-Viral Resistance Against Progressive COVID-19-PubMed. Nutrients 2020, 12, 2358. Available online: https:/ / pubmed.ncbi.nlm.nih.gov/32784601/ (accessed on 16 April 2021). [CrossRef] [PubMed] 
77. Calder, P.; Carr, A.; Gombart, A.; Eggersdorfer, M. Optimal Nutritional Status for a Well-Functioning Immune System Is an Important Factor to Protect against Viral Infections. Nutrients 2020, 12, 1181. [CrossRef]

78. Ilie, P.C.; Stefanescu, S.; Smith, L. The Role of Vitamin D in the Prevention of Coronavirus Disease 2019 Infection and Mortality. Aging Clin. Exp. Res. 2020, 32, 1195-1198. [CrossRef]

79. Rhodes, J.M.; Subramanian, S.; Laird, E.; Kenny, R.A. Editorial: Low Population Mortality from COVID-19 in Countries South of Latitude 35 Degrees North Supports Vitamin D as a Factor Determining Severity. Aliment. Pharmacol. Ther. 2020, 51, $1434-1437$. [CrossRef]

80. Chang, T.S.; Ding, Y.; Freund, M.K.; Johnson, R.; Schwarz, T.; Yabu, J.M.; Hazlett, C.; Chiang, J.N.; Wulf, A.; UCLA Health Data Mart Working Group; et al. Prior Diagnoses and Medications as Risk Factors for COVID-19 in a Los Angeles Health System; Infectious Diseases (except HIV/AIDS). medRxiv 2020. [CrossRef]

81. Mendy, A.; Apewokin, S.; Wells, A.A.; Morrow, A.L. Factors Associated with Hospitalization and Disease Severity in a Racially and Ethnically Diverse Population of COVID-19 Patients, Epidemiology. medRxiv 2020. [CrossRef]

82. De Haan, K.; Groeneveld, A.J.; de Geus, H.R.; Egal, M.; Struijs, A. Vitamin D Deficiency as a Risk Factor for Infection, Sepsis and Mortality in the Critically Ill: Systematic Review and Meta-Analysis. Crit. Care 2014, 18, 660. [CrossRef] [PubMed]

83. EFSA Panel on Dietetic Products, Nutrition and Allergies (NDA) Scientific Opinion on the Tolerable Upper Intake Level of Vitamin D. EFSA J. 2012, 10, 1-45. [CrossRef]

84. Martineau, A.R.; Jolliffe, D.A.; Hooper, R.L.; Greenberg, L.; Aloia, J.F.; Bergman, P.; Dubnov-Raz, G.; Esposito, S.; Ganmaa, D.; Ginde, A.A.; et al. Vitamin D Supplementation to Prevent Acute Respiratory Tract Infections: Systematic Review and Meta-Analysis of Individual Participant Data. BMJ 2017, 356, i6583. [CrossRef] [PubMed]

85. Gruber-Bzura, B.M. Vitamin D and Influenza-Prevention or Therapy? Int. J. Mol. Sci. 2018, 19, 2419. [CrossRef] [PubMed]

86. Fabbri, A.; Infante, M.; Ricordi, C. Editorial-Vitamin D Status: A Key Modulator of Innate Immunity and Natural Defense from Acute Viral Respiratory Infections. Eur. Rev. Med. Pharmacol. Sci. 2020, 24, 4048-4052. [CrossRef] [PubMed]

87. Cannell, J.J.; Vieth, R.; Umhau, J.C.; Holick, M.F.; Grant, W.B.; Madronich, S.; Garland, C.F.; Giovannucci, E. Epidemic Influenza and Vitamin D. Epidemiol. Infect. 2006, 134, 1129-1140. [CrossRef]

88. Bartosik-Psujek, H.; Psujek, M. Vitamin D as an Immune Modulator in Multiple Sclerosis. Neurol. Neurochir. Pol. 2019, 53, 113-122. [CrossRef]

89. Grant, W.B.; Lahore, H.; McDonnell, S.L.; Baggerly, C.A.; French, C.B.; Aliano, J.L.; Bhattoa, H.P. Evidence That Vitamin D Supplementation Could Reduce Risk of Influenza and COVID-19 Infections and Deaths. Nutrients 2020, 12, 988. [CrossRef]

90. Pereira, M.; Dantas Damascena, A.; Galvão Azevedo, L.M.; de Almeida Oliveira, T.; da Mota Santana, J. Vitamin D Deficiency Aggravates COVID-19: Systematic Review and Meta-Analysis. Crit. Rev. Food Sci. Nutr. 2020, 4, 1-9. [CrossRef]

91. Shoemark, D.K.; Colenso, C.K.; Toelzer, C.; Gupta, K.; Sessions, R.B.; Davidson, A.D.; Berger, I.; Schaffitzel, C.; Spencer, J.; Mulholland, A.J. Molecular Simulations Suggest Vitamins, Retinoids and Steroids as Ligands of the Free Fatty Acid Pocket of the SARS-CoV-2 Spike Protein*. Angew. Chem. Int. Ed. Engl. 2021, 60, 7098-7110. [CrossRef] [PubMed]

92. Hamulka, J.; Jeruszka-Bielak, M.; Górnicka, M.; Drywień, M.E.; Zielinska-Pukos, M.A. Dietary Supplements during COVID-19 Outbreak. Results of Google Trends Analysis Supported by PLifeCOVID-19 Online Studies. Nutrients 2020, 13, 54. [CrossRef]

93. Rastogi, A.; Bhansali, A.; Khare, N.; Suri, V.; Yaddanapudi, N.; Sachdeva, N.; Puri, G.D.; Malhotra, P. Short Term, High-Dose Vitamin D Supplementation for COVID-19 Disease: A Randomised, Placebo-Controlled, Study (SHADE Study). Postgrad. Med. J. 2020, 12, 1-4. [CrossRef] [PubMed]

94. Farid, N.; Rola, N.; Koch, E.A.T.; Nakhoul, N. Active Vitamin D Supplementation and COVID-19 Infections: Re view. Ir. J. Med. Sci. 2021, 6, 1-4. [CrossRef]

95. Vyas, N.; Kurian, S.J.; Bagchi, D.; Manu, M.K.; Saravu, K.; Unnikrishnan, M.K.; Mukhopadhyay, C.; Rao, M.; Miraj, S.S. Vitamin D in Prevention and Treatment of COVID-19: Current Perspective and Future Prospects. J. Am. Coll. Nutr. 2020, 1-14. [CrossRef] [PubMed]

96. Luo, X.; Liao, Q.; Shen, Y.; Li, H.; Cheng, L. Vitamin D Deficiency Is Inversely Associated with COVID-19 Incidence and Disease Severity in Chinese People. J. Nutr. 2020, 151, 98-103. [CrossRef]

97. Lim, H.; Min, D.S.; Park, H.; Kim, H.P. Flavonoids Interfere with NLRP3 Inflammasome Activation. Toxicol. Appl. Pharmacol. 2018, 355, 93-102. [CrossRef] [PubMed]

98. Zhen, Y.; Zhang, H. NLRP3 Inflammasome and Inflammatory Bowel Disease. Front. Immunol. 2019, 10, 276. [CrossRef] [PubMed]

99. Kaihatsu, K.; Yamabe, M.; Ebara, Y. Antiviral Mechanism of Action of Epigallocatechin-3-O-Gallate and Its Fatty Acid Esters. Molecules 2018, 23, 2475. [CrossRef] [PubMed]

100. Xu, J.; Xu, Z.; Zheng, W. A Review of the Antiviral Role of Green Tea Catechins. Molecules 2017, 22, 1337. [CrossRef]

101. Keflie, T.S.; Biesalski, H.K. Micronutrients and Bioactive Substances: Their Potential Roles in Combating COVID-19. Nutrition 2021, 84, 111103. [CrossRef]

102. Ding, T.; Wang, S.; Zhang, X.; Zai, W.; Fan, J.; Chen, W.; Bian, Q.; Luan, J.; Shen, Y.; Zhang, Y.; et al. Kidney Protection Effects of Dihydroquercetin on Diabetic Nephropathy through Suppressing ROS and NLRP3 Inflammasome. Phytomed. Int. J. Phytother. Phytopharm. 2018, 41, 45-53. [CrossRef]

103. Choe, J.-Y.; Kim, S.-K. Quercetin and Ascorbic Acid Suppress Fructose-Induced NLRP3 Inflammasome Activation by Blocking Intracellular Shuttling of TXNIP in Human Macrophage Cell Lines. Inflammation 2017, 40, 980-994. [CrossRef] 
104. Dabbagh-Bazarbachi, H.; Clergeaud, G.; Quesada, I.M.; Ortiz, M.; O’Sullivan, C.K.; Fernández-Larrea, J.B. Zinc Ionophore Activity of Quercetin and Epigallocatechin-Gallate: From Hepa 1-6 Cells to a Liposome Model. J. Agric. Food Chem. 2014, 62, 8085-8093. [CrossRef]

105. Fu, S.; Xu, L.; Li, S.; Qiu, Y.; Liu, Y.; Wu, Z.; Ye, C.; Hou, Y.; Hu, C.-A.A. Baicalin Suppresses NLRP3 Inflammasome and Nuclear Factor-Kappa B (NF-KB) Signaling during Haemophilus Parasuis Infection. Vet. Res. 2016, 47, 80. [CrossRef]

106. Sun, Y.; Zhao, Y.; Yao, J.; Zhao, L.; Wu, Z.; Wang, Y.; Pan, D.; Miao, H.; Guo, Q.; Lu, N. Wogonoside Protects against Dextran Sulfate Sodium-Induced Experimental Colitis in Mice by Inhibiting NF-KB and NLRP3 Inflammasome Activation. Biochem. Pharmacol. 2015, 94, 142-154. [CrossRef]

107. Zhu, X.; Shi, J.; Li, H. Liquiritigenin Attenuates High Glucose-Induced Mesangial Matrix Accumulation, Oxidative Stress, and Inflammation by Suppression of the NF-KB and NLRP3 Inflammasome Pathways. Biomed. Pharmacother. 2018, 106, 976-982. [CrossRef] [PubMed]

108. Chen, H.; Lin, H.; Xie, S.; Huang, B.; Qian, Y.; Chen, K.; Niu, Y.; Shen, H.-M.; Cai, J.; Li, P.; et al. Myricetin Inhibits NLRP3 Inflammasome Activation via Reduction of ROS-Dependent Ubiquitination of ASC and Promotion of ROS-Independent NLRP3 Ubiquitination. Toxicol. Appl. Pharmacol. 2019, 365, 19-29. [CrossRef] [PubMed]

109. Pluta, R.; Januszewski, S.; Czuczwar, S.J. Myricetin as a Promising Molecule for the Treatment of Post-Ischemic Brain Neurodegeneration. Nutrients 2021, 13, 342. [CrossRef]

110. Yin, H.; Guo, Q.; Li, X.; Tang, T.; Li, C.; Wang, H.; Sun, Y.; Feng, Q.; Ma, C.; Gao, C.; et al. Curcumin Suppresses IL-1 $\beta$ Secretion and Prevents Inflammation through Inhibition of the NLRP3 Inflammasome. J. Immunol. 2018, 200, 2835-2846. [CrossRef]

111. Wen, C.-C.; Kuo, Y.-H.; Jan, J.-T.; Liang, P.-H.; Wang, S.-Y.; Liu, H.-G.; Lee, C.-K.; Chang, S.-T.; Kuo, C.-J.; Lee, S.-S.; et al. Specific Plant Terpenoids and Lignoids Possess Potent Antiviral Activities against Severe Acute Respiratory Syndrome Coronavirus. J. Med. Chem. 2007, 50, 4087-4095. [CrossRef] [PubMed]

112. Shakibaei, M.; John, T.; Schulze-Tanzil, G.; Lehmann, I.; Mobasheri, A. Suppression of NF-KappaB Activation by Curcumin Leads to Inhibition of Expression of Cyclo-Oxygenase-2 and Matrix Metalloproteinase-9 in Human Articular Chondrocytes: Implications for the Treatment of Osteoarthritis. Biochem. Pharmacol. 2007, 73, 1434-1445. [CrossRef]

113. Knobloch, J.; Wahl, C.; Feldmann, M.; Jungck, D.; Strauch, J.; Stoelben, E.; Koch, A. Resveratrol Attenuates the Release of Inflammatory Cytokines from Human Bronchial Smooth Muscle Cells Exposed to Lipoteichoic Acid in Chronic Obstructive Pulmonary Disease. Basic Clin. Pharmacol. Toxicol. 2014, 114, 202-209. [CrossRef]

114. Ramdani, L.H.; Bachari, K. Potential Therapeutic Effects of Resveratrol against SARS-CoV-2. Acta Virol. 2020, 64, 276-280. [CrossRef]

115. Shaito, A.; Posadino, A.M.; Younes, N.; Hasan, H.; Halabi, S.; Alhababi, D.; Al-Mohannadi, A.; Abdel-Rahman, W.M.; Eid, A.H.; Nasrallah, G.K.; et al. Potential Adverse Effects of Resveratrol: A Literature Review. Int. J. Mol. Sci. 2020, 21, 2084. [CrossRef]

116. Giordo, R.; Zinellu, A.; Eid, A.H.; Pintus, G. Therapeutic Potential of Resveratrol in COVID-19-Associated Hemostatic Disorders. Molecules 2021, 26, 856. [CrossRef]

117. Farjana, M.; Moni, A.; Sohag, A.A.M.; Hasan, A.; Hannan, M.A.; Hossain, M.G.; Uddin, M.J. Repositioning Vitamin C as a Promising Option to Alleviate Complications Associated with COVID-19. Infect. Chemother. 2020, 52, 461-477. [CrossRef]

118. Mikirova, N.; Hunninghake, R. Effect of High Dose Vitamin C on Epstein-Barr Viral Infection. Med. Sci. Monit. Int. Med. J. Exp. Clin. Res. 2014, 20, 725-732. [CrossRef]

119. Fowler Iii, A.A.; Kim, C.; Lepler, L.; Malhotra, R.; Debesa, O.; Natarajan, R.; Fisher, B.J.; Syed, A.; DeWilde, C.; Priday, A.; et al. Intravenous Vitamin $\mathrm{C}$ as Adjunctive Therapy for Enterovirus/Rhinovirus Induced Acute Respiratory Distress Syndrome. World J. Crit. Care Med. 2017, 6, 85-90. [CrossRef]

120. Fisher, B.J.; Seropian, I.M.; Kraskauskas, D.; Thakkar, J.N.; Voelkel, N.F.; Fowler, A.A.; Natarajan, R. Ascorbic Acid Attenuates Lipopolysaccharide-Induced Acute Lung Injury. Crit. Care Med. 2011, 39, 1454-1460. [CrossRef] [PubMed]

121. Fowler, A.A.; Syed, A.A.; Knowlson, S.; Sculthorpe, R.; Farthing, D.; DeWilde, C.; Farthing, C.A.; Larus, T.L.; Martin, E.; Brophy, D.F.; et al. Phase I Safety Trial of Intravenous Ascorbic Acid in Patients with Severe Sepsis. J. Transl. Med. 2014, 12, 32. [CrossRef] [PubMed]

122. Hemilä, H.; Chalker, E. Vitamin C as a Possible Therapy for COVID-19. Infect. Chemother. 2020, 52, 222-223. [CrossRef] [PubMed]

123. Hemilä, H.; Chalker, E. Vitamin C Can Shorten the Length of Stay in the ICU: A Meta-Analysis. Nutrients 2019, 11, 708. [CrossRef]

124. Hemilä, H.; Chalker, E. Vitamin C May Reduce the Duration of Mechanical Ventilation in Critically Ill Patients: A Meta-Regression Analysis. J. Intensive Care 2020, 8, 15. [CrossRef] [PubMed]

125. Jamali Moghadam Siahkali, S.; Zarezade, B.; Koolaji, S.; Seyed Alinaghi, S.; Zendehdel, A.; Tabarestani, M.; Sekhavati Moghadam, E.; Abbasian, L.; Dehghan Manshadi, S.A.; Salehi, M.; et al. Safety and Effectiveness of High-Dose Vitamin C in Patients with COVID-19: A Randomized Open-Label Clinical Trial. Eur. J. Med. Res. 2021, 26, 20. [CrossRef]

126. Silvestri, M.; Rossi, G.A. Melatonin: Its Possible Role in the Management of Viral Infections-A Brief Review. Ital. J. Pediatr. 2013, 39, 61. [CrossRef]

127. Fernandes, P.A.; Kinker, G.S.; Navarro, B.V.; Jardim, V.C.; Ribeiro-Paz, E.D.; Córdoba-Moreno, M.O.; Santos-Silva, D.; Muxel, S.M.; Fujita, A.; Moraes, C.B.; et al. Melatonin-Index as a Biomarker for Predicting the Distribution of Presymptomatic and Asymptomatic SARS-CoV-2 Carriers. Melatonin Res. 2021, 4, 189-205. [CrossRef]

128. Hardeland, R. Melatonin and Inflammation-Story of a Double-Edged Blade. J. Pineal Res. 2018, 65, e12525. [CrossRef] [PubMed] 
129. Romero, J.M.; Grünwald, B.; Jang, G.-H.; Bavi, P.P.; Jhaveri, A.; Masoomian, M.; Fischer, S.E.; Zhang, A.; Denroche, R.E.; Lungu, I.M.; et al. A Four-Chemokine Signature Is Associated with a T-Cell-Inflamed Phenotype in Primary and Metastatic Pancreatic Cancer. Clin. Cancer Res. Off. J. Am. Assoc. Cancer Res. 2020, 26, 1997-2010. [CrossRef]

130. Skalny, A.V.; Rink, L.; Ajsuvakova, O.P.; Aschner, M.; Gritsenko, V.A.; Alekseenko, S.I.; Svistunov, A.A.; Petrakis, D.; Spandidos, D.A.; Aaset, J.; et al. Zinc and Respiratory Tract Infections: Perspectives for COVID-19 (Review)—PubMed. Int. J. Mol. Med. 2020, 46, 17-26. Available online: https:/ / pubmed.ncbi.nlm.nih.gov/32319538/ (accessed on 16 April 2021). [CrossRef]

131. Phillips, J.M.; Gallagher, T.; Weiss, S.R. Neurovirulent Murine Coronavirus JHM.SD Uses Cellular Zinc Metalloproteases for Virus Entry and Cell-Cell Fusion. J. Virol. 2017, 91, e01564-16. [CrossRef]

132. Han, Y.-S.; Chang, G.-G.; Juo, C.-G.; Lee, H.-J.; Yeh, S.-H.; Hsu, J.T.-A.; Chen, X. Papain-Like Protease 2 (PLP2) from Severe Acute Respiratory Syndrome Coronavirus (SARS-CoV): Expression, Purification, Characterization, and Inhibition. Biochemistry 2005, 44, 10349-10359. [CrossRef]

133. Tuerk, M.J.; Fazel, N. Zinc Deficiency. Curr. Opin. Gastroenterol. 2009, 25, 136-143. [CrossRef] [PubMed]

134. Barnett, J.B.; Hamer, D.H.; Meydani, S.N. Low Zinc Status: A New Risk Factor for Pneumonia in the Elderly? Nutr. Rev. 2010, 68, 30-37. [CrossRef] [PubMed]

135. Bonaventura, P.; Benedetti, G.; Albarède, F.; Miossec, P. Zinc and Its Role in Immunity and Inflammation. Autoimmun. Rev. 2015, 14, 277-285. [CrossRef]

136. Iyigundogdu, Z.U.; Demir, O.; Asutay, A.B.; Sahin, F. Developing Novel Antimicrobial and Antiviral Textile Products-PubMed. Appl. Biochem. Biotechnol. 2017, 181, 1155-1166. Available online: https:/ / pubmed.ncbi.nlm.nih.gov/27734286/ (accessed on 16 April 2021). [CrossRef]

137. Brewer, J.; Gomez Marti, J.L.; Brufsky, A. Potential Interventions for SARS-CoV-2 Infections: Zinc Showing Promise. J. Med. Virol. 2021, 93, 1201-1203. [CrossRef] [PubMed]

138. Anderson, G. Psychological Stress and Covid-19: Interactions with Gut Microbiome and Circadian Rhythm in Driving Symptom Severity; CRC: London, UK, 2020.

139. Vuille-Dit-Bille, R.N.; Liechty, K.W.; Verrey, F.; Guglielmetti, L.C. SARS-CoV-2 Receptor ACE2 Gene Expression in Small Intestine Correlates with Age. Amino Acids 2020, 52, 1063-1065. [CrossRef] [PubMed]

140. Zuo, T.; Zhang, F.; Lui, G.C.Y.; Yeoh, Y.K.; Li, A.Y.L.; Zhan, H.; Wan, Y.; Chung, A.C.K.; Cheung, C.P.; Chen, N.; et al. Alterations in Gut Microbiota of Patients With COVID-19 During Time of Hospitalization. Gastroenterology 2020, 159, 944-955.e8. [CrossRef] [PubMed]

141. Chhibber-Goel, J.; Gopinathan, S.; Sharma, A. Interplay between Severities of COVID-19 and the Gut Microbiome: Implications of Bacterial Co-Infections? Gut Pathog. 2021, 13, 14. [CrossRef] [PubMed]

142. Xu, Y.; Li, X.; Zhu, B.; Liang, H.; Fang, C.; Gong, Y.; Guo, Q.; Sun, X.; Zhao, D.; Shen, J.; et al. Characteristics of Pediatric SARS-CoV-2 Infection and Potential Evidence for Persistent Fecal Viral Shedding. Nat. Med. 2020, 26, 502-505. [CrossRef]

143. Effenberger, M.; Grabherr, F.; Mayr, L.; Schwaerzler, J.; Nairz, M.; Seifert, M.; Hilbe, R.; Seiwald, S.; Scholl-Buergi, S.; Fritsche, G.; et al. Faecal Calprotectin Indicates Intestinal Inflammation in COVID-19. Gut 2020, 69, 1543-1544. [CrossRef]

144. Costela-Ruiz, V.J.; Illescas-Montes, R.; Puerta-Puerta, J.M.; Ruiz, C.; Melguizo-Rodríguez, L. SARS-CoV-2 Infection: The Role of Cytokines in COVID-19 Disease. Cytokine Growth Factor Rev. 2020, 54, 62-75. [CrossRef]

145. Van der Lelie, D.; Taghavi, S. COVID-19 and the Gut Microbiome: More than a Gut Feeling. mSystems 2020, 5. [CrossRef]

146. Tang, L.; Gu, S.; Gong, Y.; Li, B.; Lu, H.; Li, Q.; Zhang, R.; Gao, X.; Wu, Z.; Zhang, J.; et al. Clinical Significance of the Correlation between Changes in the Major Intestinal Bacteria Species and COVID-19 Severity. Engineering 2020, 6, 1178-1184. [CrossRef]

147. Zuo, T.; Liu, Q.; Zhang, F.; Lui, G.C.-Y.; Tso, E.Y.; Yeoh, Y.K.; Chen, Z.; Boon, S.S.; Chan, F.K.; Chan, P.K.; et al. Depicting SARS-CoV-2 Faecal Viral Activity in Association with Gut Microbiota Composition in Patients with COVID-19. Gut 2021, 70, 276-284. [CrossRef]

148. Chunxi, L.; Haiyue, L.; Yanxia, L.; Jianbing, P.; Jin, S. The Gut Microbiota and Respiratory Diseases: New Evidence. J. Immunol. Res. 2020, 2020, 2340670. [CrossRef]

149. Guillemard, E.; Tanguy, J.; Flavigny, A.; de la Motte, S.; Schrezenmeir, J. Effects of Consumption of a Fermented Dairy Product Containing the Probiotic Lactobacillus Casei DN-114 001 on Common Respiratory and Gastrointestinal Infections in Shift Workers in a Randomized Controlled Trial. J. Am. Coll. Nutr. 2010, 29, 455-468. [CrossRef]

150. Morrow, L.E.; Kollef, M.H.; Casale, T.B. Probiotic Prophylaxis of Ventilator-Associated Pneumonia: A Blinded, Randomized, Controlled Trial. Am. J. Respir. Crit. Care Med. 2010, 182, 1058-1064. [CrossRef]

151. Gohil, K.; Samson, R.; Dastager, S.; Dharne, M. Probiotics in the Prophylaxis of COVID-19: Something Is Better than Nothing. 3 Biotech 2021, 11, 1. [CrossRef] [PubMed]

152. Kothari, D.; Patel, S.; Kim, S.-K. Probiotic Supplements Might Not Be Universally-Effective and Safe: A Review. Biomed. Pharmacother. 2019, 111, 537-547. [CrossRef] [PubMed]

153. Sattar, N.; McInnes, I.B.; McMurray, J.J.V. Obesity Is a Risk Factor for Severe COVID-19 Infection: Multiple Potential Mechanisms. Circulation 2020, 142, 4-6. [CrossRef] [PubMed]

154. Angelidi, A.M.; Belanger, M.J.; Mantzoros, C.S. Commentary: COVID-19 and Diabetes Mellitus: What We Know, How Our Patients Should Be Treated Now, and What Should Happen Next. Metabolism 2020, 107, 154245. [CrossRef] 
155. Palaiodimos, L.; Kokkinidis, D.G.; Li, W.; Karamanis, D.; Ognibene, J.; Arora, S.; Southern, W.N.; Mantzoros, C.S. Severe Obesity, Increasing Age and Male Sex Are Independently Associated with Worse in-Hospital Outcomes, and Higher in-Hospital Mortality, in a Cohort of Patients with COVID-19 in the Bronx, New York. Metabolism 2020, 108, 154262. [CrossRef]

156. de Faria Coelho-Ravagnani, C.; Corgosinho, F.C.; Sanches, F.L.F.Z.; Prado, C.M.M.; Laviano, A.; Mota, J.F. Dietary Recommendations during the COVID-19 Pandemic. Nutr. Rev. 2021, 79, 382-393. [CrossRef]

157. Kruglikov, I.L.; Scherer, P.E. The Role of Adipocytes and Adipocyte-Like Cells in the Severity of COVID-19 Infections. Obesity 2020, 28, 1187-1190. [CrossRef]

158. Angelidi, A.M.; Kokkinos, A.; Katechaki, E.; Ros, E.; Mantzoros, C.S. Mediterranean Diet as a Nutritional Approach for COVID-19. Metabolism 2021, 114, 154407. [CrossRef] [PubMed]

159. Mozaffarian, D.; Wu, J.H.Y. Flavonoids, Dairy Foods, and Cardiovascular and Metabolic Health: A Review of Emerging Biologic Pathways. Circ. Res. 2018, 122, 369-384. [CrossRef]

160. Del Rio, D.; Rodriguez-Mateos, A.; Spencer, J.P.E.; Tognolini, M.; Borges, G.; Crozier, A. Dietary (Poly)Phenolics in Human Health: Structures, Bioavailability, and Evidence of Protective Effects against Chronic Diseases-PubMed. Antioxid. Redox Signal. 2013, 18, 1818-1892. Available online: https:/ / pubmed.ncbi.nlm.nih.gov/22794138/ (accessed on 18 May 2021). [CrossRef]

161. Mehta, P.; McAuley, D.F.; Brown, M.; Sanchez, E.; Tattersall, R.S.; Manson, J.J. HLH Across Speciality Collaboration, UK COVID-19: Consider Cytokine Storm Syndromes and Immunosuppression. Lancet 2020, 395, 1033-1034. [CrossRef]

162. Gómez-Mesa, J.E.; Galindo-Coral, S.; Montes, M.C.; Muñoz Martin, A.J. Thrombosis and Coagulopathy in COVID-19. Curr. Probl. Cardiol. 2021, 46, 100742. [CrossRef]

163. Kang, I.; Buckner, T.; Shay, N.F.; Gu, L.; Chung, S. Improvements in Metabolic Health with Consumption of Ellagic Acid and Subsequent Conversion into Urolithins: Evidence and Mechanisms. Adv. Nutr. 2016, 7, 961-972. [CrossRef]

164. Andriantsitohaina, R.; Auger, C.; Chataigneau, T.; Étienne-Selloum, N.; Li, H.; Martínez, M.C.; Schini-Kerth, V.B.; Laher, I. Molecular Mechanisms of the Cardiovascular Protective Effects of Polyphenols. Br. J. Nutr. 2012, 108, 1532-1549. [CrossRef]

165. Ruiz-Núñez, B.; Dijck-Brouwer, D.A.J.; Muskiet, F.A.J. The Relation of Saturated Fatty Acids with Low-Grade Inflammation and Cardiovascular Disease. J. Nutr. Biochem. 2016, 36, 20. [CrossRef]

166. Hunsche, C.; Hernandez, O.; Gheorghe, A.; Díaz, L.E.; Marcos, A.; De la Fuente, M. Immune Dysfunction and Increased Oxidative Stress State in Diet-Induced Obese Mice Are Reverted by Nutritional Supplementation with Monounsaturated and n-3 Polyunsaturated Fatty Acids. Eur. J. Nutr. 2018, 57, 1123-1135. [CrossRef] [PubMed]

167. Gutiérrez, S.; Svahn, S.L.; Johansson, M.E. Effects of Omega-3 Fatty Acids on Immune Cells. Int. J. Mol. Sci. 2019, $20,5028$. [CrossRef] [PubMed]

168. Gorzynik-Debicka, M.; Przychodzen, P.; Cappello, F.; Kuban-Jankowska, A.; Marino Gammazza, A.; Knap, N.; Wozniak, M.; Gorska-Ponikowska, M. Potential Health Benefits of Olive Oil and Plant Polyphenols. Int. J. Mol. Sci. 2018, 19, 686. [CrossRef]

169. Black, D.S.; Slavich, G.M. Mindfulness Meditation and the Immune System: A Systematic Review of Randomized Controlled Trials. Ann. N. Y. Acad. Sci. 2016, 1373, 13-24. [CrossRef]

170. Iwata, M.; Ota, K.T.; Li, X.-Y.; Sakaue, F.; Li, N.; Dutheil, S.; Banasr, M.; Duric, V.; Yamanashi, T.; Kaneko, K.; et al. Psychological Stress Activates the Inflammasome via Release of Adenosine Triphosphate and Stimulation of the Purinergic Type 2X7 Receptor. Biol. Psychiatry 2016, 80, 12-22. [CrossRef] [PubMed] 